\title{
Gully formation in the McMurdo Dry Valleys, Antarctica: multiple sources of water, temporal sequence and relative importance in gully erosion and deposition processes
}

\author{
JAMES L. DICKSON ${ }^{1,2 *}$, JAMES W. HEAD ${ }^{2}$, JOSEPH S. LEVY ${ }^{3,4}$, \\ GARETH A. MORGAN ${ }^{5} \&$ DAVID R. MARCHANT 6 \\ ${ }^{1}$ Division of Geological and Planetary Sciences, California Institute of Technology, \\ Pasadena, CA 91125, USA \\ ${ }^{2}$ Department of Earth, Environmental and Planetary Sciences, Brown University, \\ Providence, RI 02906, USA \\ ${ }^{3}$ Institute for Geophysics, University of Texas, Austin, TX 78758, USA \\ ${ }^{4}$ Present address: Department of Geology, Colgate University, Hamilton, NY 13346, USA \\ ${ }^{5}$ Center for Earth and Planetary Studies, Smithsonian Institution, Washington, DC 20013, USA \\ ${ }^{6}$ Department of Earth and Environment, Boston University, Boston, MA 02215, USA
}

*Correspondence: jdickson@caltech.edu

\begin{abstract}
We report on a decade of fieldwork designed to determine the conditions required for erosion of Mars-like gully channels in the McMurdo Dry Valleys (MDV) of Antarctica. We have outlined the major factors in the morphological evolution of gullies in the Inland Mixed Zone of the MDV: (1) the distribution of ice sources; (2) the temporal aspects of ice melting; and (3) the relative significance of melting events in gullies. We show that significant erosion of gully channels can be achieved if geometrical and environmental conditions combine to concentrate ice where it can rapidly melt. In contrast, annual melting of surface ice and snow deposits during late-season discharge events contribute to transport of water, but flux rarely surpasses the infiltration capacity of the active layer. These small discharge events do not erode channels of significant width. Even when the flux is sufficient to carve a $c$. 10-20 cm deep channel during late summer (JanuaryFebruary) runoff, these small channels seldom persist through multiple seasons, because they are seasonally muted and filled with aeolian deposits. We briefly discuss the application of these results to the study of gully systems on Mars.
\end{abstract}

Supplementary material: Eight videos showing activity and events are available at https://doi. org/10.6084/m9.figshare.c.3935992

Martian gullies are important tools for understanding the fate of volatiles on the surface in the late Amazonian. Since their discovery (Malin \& Edgett 2000), it has been clear that gullies are climate-related and involve phase changes of volatiles at the surface or within the shallow subsurface. A decade of changedetection efforts has shown that modification of existing gullies is temporally associated with the loss of $\mathrm{CO}_{2}$ frost at the surface (Dundas et al. 2015), with rare instances being more consistent with the removal of $\mathrm{H}_{2} \mathrm{O}$ frost (Vincendon 2015). This has promoted a fundamental question: is the erosion and deposition observed today sufficient to gradually form gullies over thousands of years, or does contemporary activity represent only the ephemeral modification of larger gullies that formed from higherenergy events under different climate conditions?
On Earth, the same question can be asked about gullies that form in the frozen polar desert of Antarctica and the Transantarctic Mountains (Marchant \& Head 2007; Hauber et al. this volume, in review). The combination of extremely low mean annual temperatures $\left(c .-18^{\circ} \mathrm{C}\right.$ : Riordan 1973; Doran et al. 2002), hyper-arid conditions (3-50 mm water equivalent snowfall: Thompson et al. 1971; Thompson 1973; Fountain et al. 1999), an absence of pluvial activity of any significance and a lack of vascular plants makes the McMurdo Dry Valleys (MDV) a more appropriate geomorphological analogue for Mars than any other location on Earth (Marchant \& Head 2007). Despite cold and dry conditions, sinuous channels (McKnight et al. 1999) have formed and are currently evolving in this desiccated landscape. Unlike larger glacier-fed streams, however, which 
experience near-continuous flow during austral summer (December-January), ephemeral gullies permit the documentation of flow initiation, a signal generally obscured in higher-flux streams. Further, while we are currently unable to study gullies on Mars in situ, deconstructing the behaviour of MDV gullies in detail provides hypotheses and constraints that can be used to make more detailed testable predictions about their counterparts on Mars. In this contribution, we utilize a variety of environmental monitoring techniques to document the presence of water snow/ice reservoirs, their volumes and distribution in relation to the gullies, the conditions under which they undergo melting, and their relative contributions to erosion and deposition in MDV gully systems.

Despite their small size $\left(c .4500 \mathrm{~km}^{2}\right.$ of ice-free area, slightly more than the size of the State of Rhode Island) (Fig. 1b) (Levy 2013), the MDV exhibit a wide spectrum of glacial, periglacial and fluvial landforms, the distribution of which is controlled by the range in climate conditions that occur in the Trans-Antarctic Mountains at this location (Marchant \& Denton 1996; Marchant \& Head 2007; Head \& Marchant 2014). Based on elevation, distance from the coast, temperature and meltwater availability, a hydrological continuum exists in the MDV (Head \& Marchant 2014; Levy 2015). This range of processes and landforms is bracketed by: (1) coastal environments where peak summer (January) conditions produce enough surface melting of sub-aerial cold-based glaciers to produce stream channels tens of kilometres long (Conovitz et al. 1998; McKnight et al. 1999); and (2) high-elevation inland environments devoid of significant geomorphological evidence for surface or near-surface water flow, potentially since the Miocene (Sugden et al. 1995; Marchant et al. 2002).

The transition between these two end members, referred to as the Inland Mixed Zone (IMZ) in Marchant \& Head (2007) and Zone 2 in Marchant \& Denton (1996), hosts features indicative of fluvial transport, but not as widespread nor at the scale observed at the coast, with fluvial activity concentrated primarily on warmer equator-facing slopes (Marchant \& Denton 1996; Fountain et al. 1999). It follows, then, that the upper extent of this zone represents the coldest and driest region of the MDV where concentrated fluvial erosion and transport can occur.

Our study site, the South Fork of Upper Wright Valley, is found at this upper extent of the IMZ (Fig. 1b, c) (Marchant \& Head 2007). Two narrow gullies incise the southern equator-facing wall of the valley (Fig. 2). These channels are prominent evidence for fluvial activity that is hydrologically distinct from streams in the neighbouring Taylor Valley, in that these gullies lack a large glacial meltwater source. Like gullies on Mars, it is unknown whether these channels form through iterative annual erosion from small amounts of summer (DecemberFebruary) melting or through punctuated and anomalous high-energy flow events. Determining how these gullies form under conditions of limited and episodic liquid-water availability will provide the minimum requirements for what is necessary to create a fluvial transport system on Earth.

Here, we use a decade of field data and observations in South Fork to test the hypothesis that previously documented peak-season melting of surface snow deposits (Levy et al. 2009) is sufficient, over long timescales, to erode gully channels gradually in the McMurdo Dry Valleys. This terrestrial investigation allows us to assess the conditions required in polar deserts on Earth to produce net erosion in gully channels and accumulation on alluvial fans.

\section{South Fork geographical and hydrological setting}

Upper Wright Valley is divided into two smaller east-west-trending troughs: North Fork and South Fork. Separating the two is a $c .700 \mathrm{~m}$-tall mesa referred to as the 'Dais' (Fig. 2), thought to represent a remnant from the glacial incision and subsequent subglacial floods that helped to carve and modify the valley (Lewis et al. 2006). This valley bifurcation provides an unusually narrow valley width $(c .4 \mathrm{~km}$ at the maximum extent) for South Fork between the Dais to the north and the Asgard Range to the south. The east-west orientation of the valley provides pole-facing (northern) and equator-facing (southern) valley walls that each approach the angle of repose $\left(c .30^{\circ}\right)$ near the top of the slope, before transitioning into bare bedrock cliffs. The floor of the valley consists of a primarily granitic diamicton with a continuous, low-permeability ice-cement table (and underlying permafrost) beneath an active layer that averages $c .20 \mathrm{~cm}$ in thickness.

Several gullies (with channels $<5 \mathrm{~m}$ wide) incise the southern (equator-facing) wall of South Fork. The two longest extend $c .3 \mathrm{~km}$ from perennial snowpacks in alcoves along the rim of the valley wall to the floor of the valley (Fig. 2). These two gullies, Gully A and Gully B (Fig. 2), occur within the watershed of an ephemeral saline pond $c .2 \mathrm{~km}$ east of Don Juan Pond that hosts an ecosystem dominated by algal mats, common amongst larger stream channels in the MDV (McKnight et al. 1999).

\section{Methods}

We documented activity within South Fork primarily using a network of nine Onset HOBO data loggers that all measured surface temperature, air temperature, solar radiation and soil moisture at the surface. 

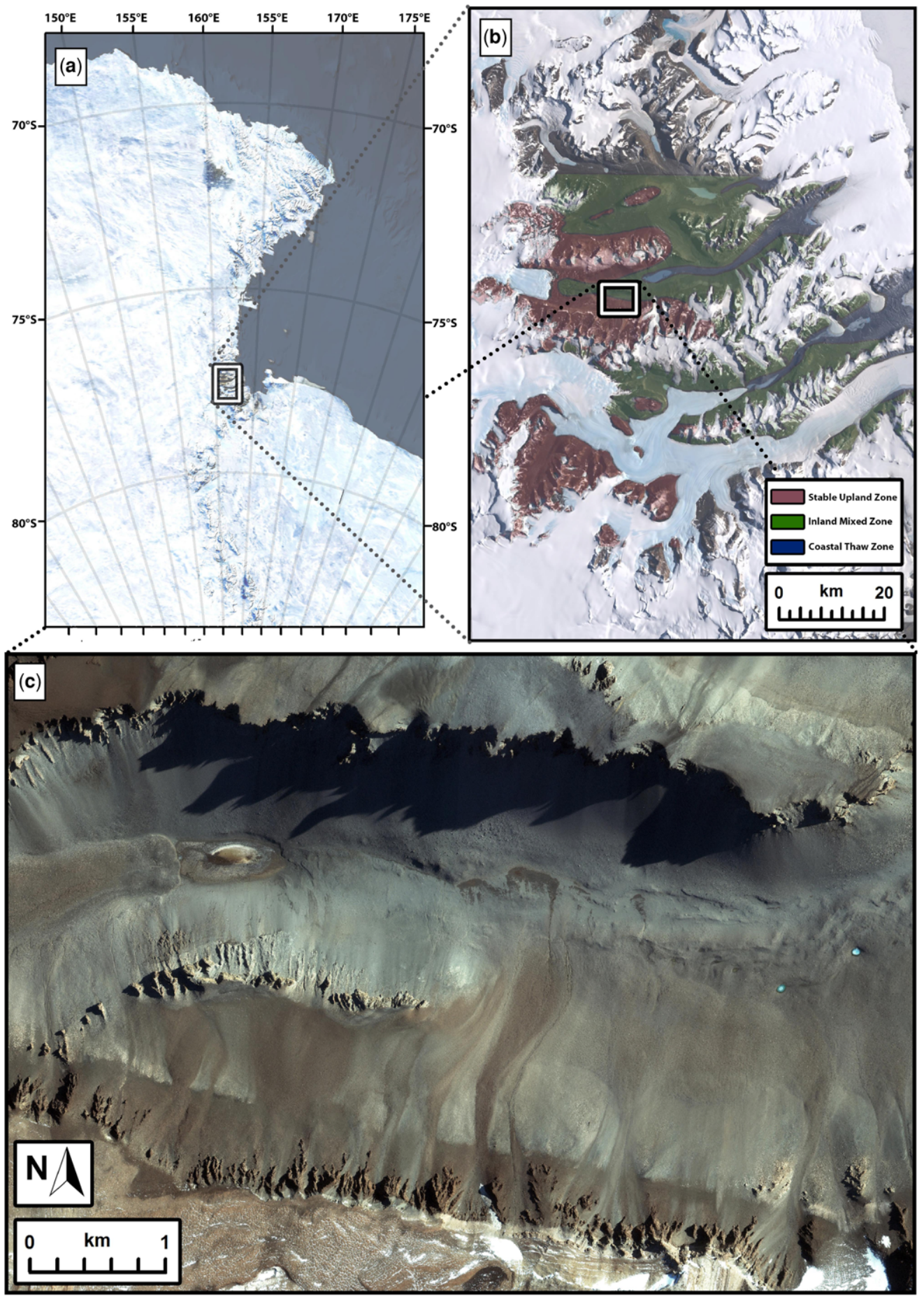

Fig. 1. (a) Landsat (Bindschadler et al. 2008) imagery of Southern Victoria Land, Antarctica. (b) Landsat visible context imagery of the McMurdo Dry Valleys. Colour overlays correspond to microclimate zones as mapped by Marchant \& Head (2007). (c) IKONOS multi-spectral image of the South Fork of Upper Wright Valley. Gullies incise only the warmer north-facing slope. 

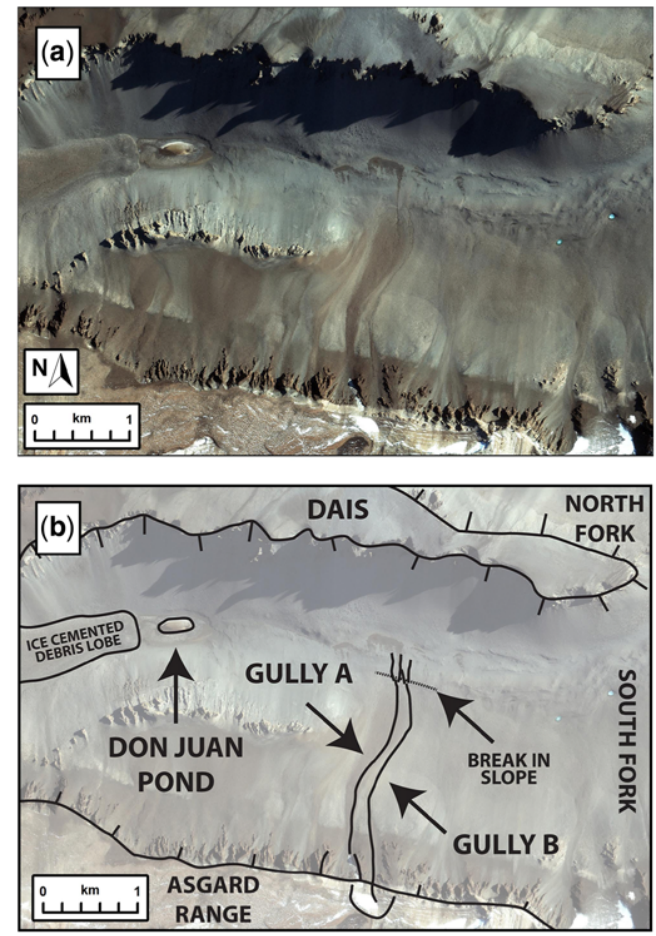

Fig. 2. (a) IKONOS multi-spectral image of the South Fork of Upper Wright Valley. (b) Major features of the South Fork of Upper Wright Valley. Gully A and Gully B are marked. Don Juan Pond is found at the lowest topographical point in South Fork.
Seven of these stations were installed on the floor of South Fork, both within the channels for Gully A and Gully B, and on their fans (Fig. 3). The final two were installed within the alcove for Gully B ('Valley Rim' in Fig. 3) and midway up the valley wall ('Valley Wall' in Fig. 3).

Multiple time-lapse imaging stations were also installed to provide high-resolution, high-frequency documentation of surface activity, similar to those used at nearby Don Juan Pond (Dickson et al. 2013). For the 2009-10 season, a station was placed on the Dais overlooking the field site (Fig. 4a, Site 1). For 2010-11 and subsequent seasons, there were two stations on the floor of South Fork: one on the northern wall overlooking both alluvial fans (Fig. 4b, Site 2) and one on the Gully A fan (Fig. 4c, Site 3).

We wrote software that synchronized input conditions recorded by the meteorological stations with the surface response documented by the timelapse cameras, as used in Dickson et al. (2013).

\section{Geomorphological observations}

Gully A emanates from a dolerite-floored alcove on the southern rim of South Fork (Figs 1c \& 2). A perennial snowpack is present in the easternmost extent of the alcove (Fig. 5), and historical overflight imagery has shown that this snowpack has persisted since at least the late 1950s, when Upper Wright Valley was first explored. A broad fan, comprised mostly of large dolerite boulders, which extends

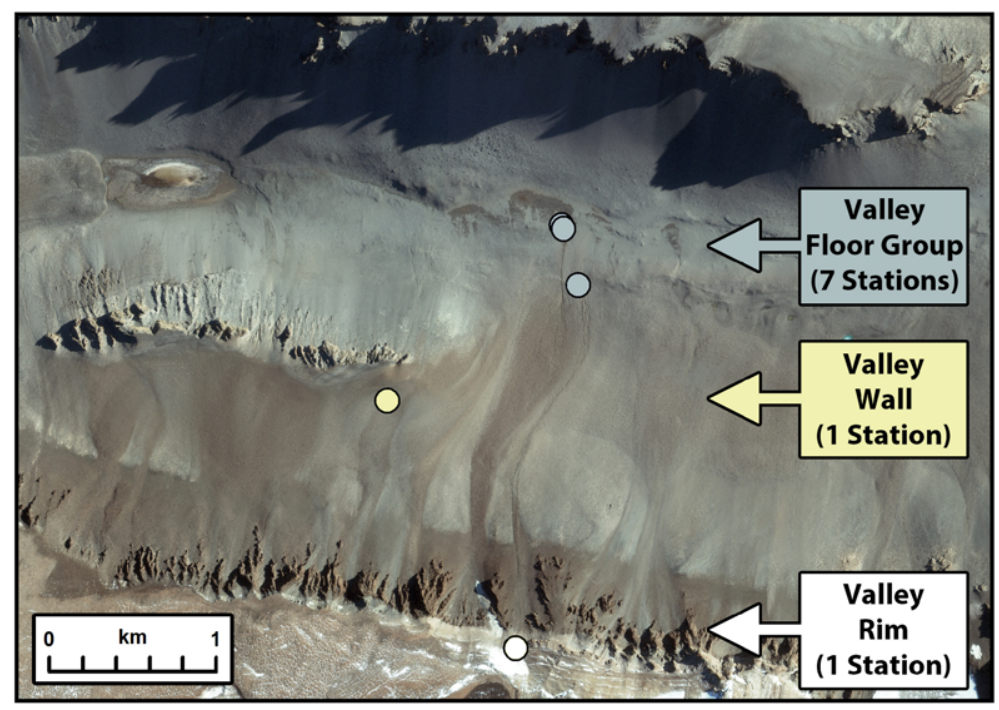

Fig. 3. Distribution of meteorological stations installed in November 2006. Emphasis for sensor selection was placed on fully characterizing the insolation and thermal environment throughout the extent of the gullies. 

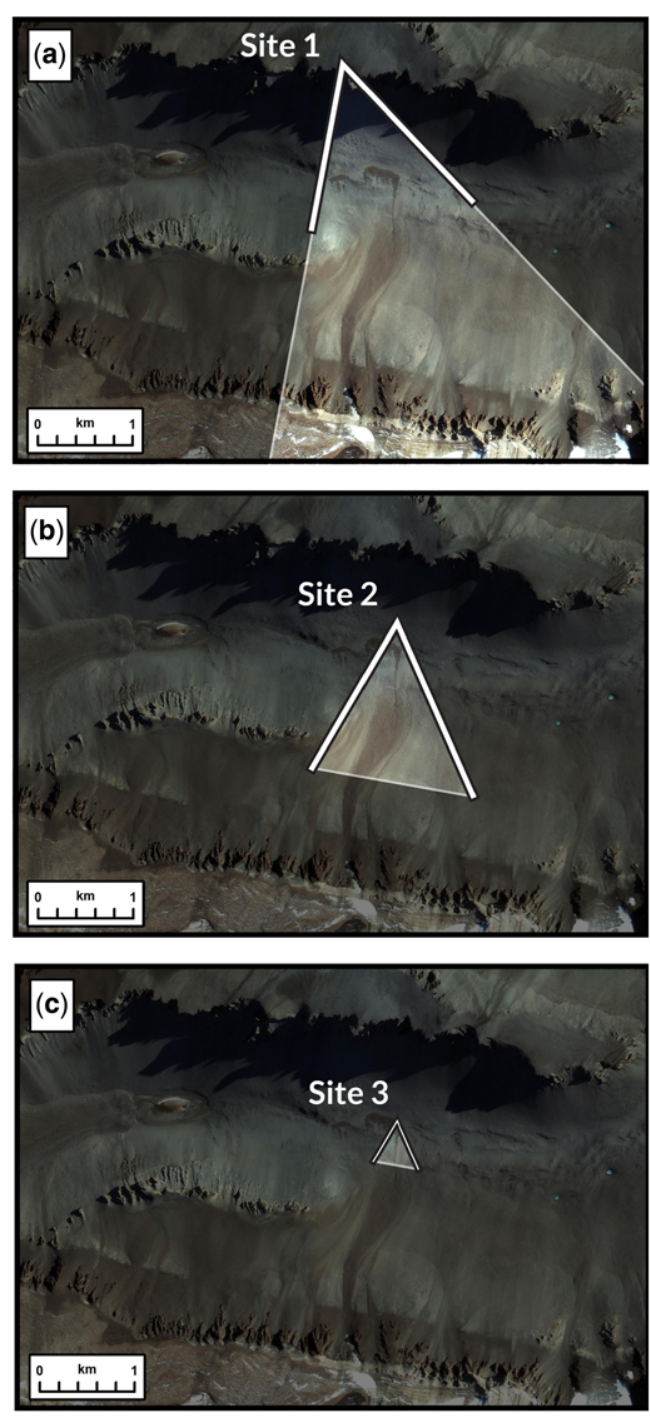

Fig. 4. (a) Vantage point for time-lapse sequences shown in Figures 7, 8, 11 and 22; see also videos 2, 3 and 5 in the Supplementary material. (b) Vantage point for time-lapse sequences in Figures 10 and 12; see also videos 6 and 7 in the Supplementary material.

(c) Vantage point for time-lapse sequence in Figure 14; see also video 8 in the Supplementary material.

close to the valley floor emanates from this alcove, and the abundance of metre-scale boulders largely obscures from view most of the channel for Gully A that runs from the alcove snowpack to the valley floor. Detailed investigations of metre-scale satellite images and field observations have determined that this channel is continuous from the snowpack to the fan on the valley floor.

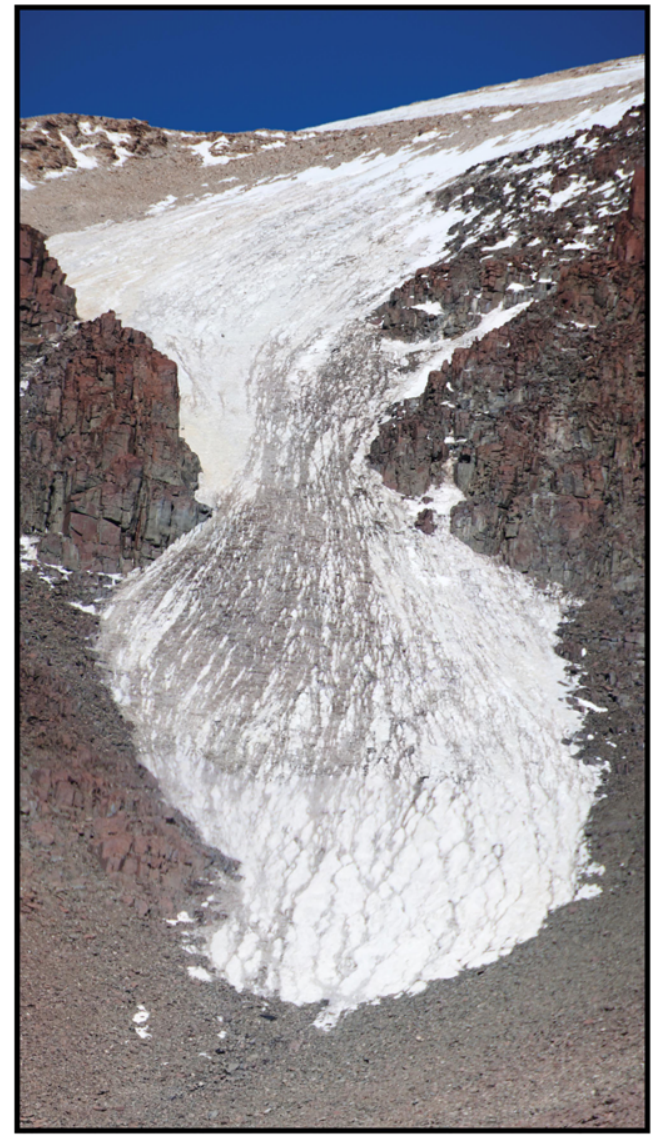

Fig. 5. Perennial snowpack in the alcove for Gully A. The image was acquired on 29 November 2010. The debris-rich snowpack is heavily dissected by stream channels that were active during the austral spring of November 2010.

Gully B emanates from a separate perennial snowpack that is perched above the dolerite alcove for Gully A. The channel that extends directly from this snowpack extends down the southern wall of South Fork at a near-consistent width. Particularly at the channel's uppermost extent, walls are leveed by boulders mostly at the $50 \mathrm{~cm}$ - and metre-scale, with some smaller rocks, which also cover much of the channel floor. The channel maintains a width of c. $3 \mathrm{~m}$ for most of its length.

Both channels for Gully A and Gully B transition from erosional to depositional near a break in slope near the valley floor (Fig. 2), which corresponds to the sinuous Upper Wright III moraine (Calkin \& Bull 1972). The measurements and observations of gully activity reported in this paper are primarily focused on activity within alluvial fans at this 
location, as that is where modern-day alluvial-fan deposition and channel scour is concentrated. The results presented here apply to modern-day modifications of existing gully systems and not the initial formation of the gullies themselves, although we propose that similar processes may have been at work when the initial gully channels were carved.

\section{Instrumentation: meteorological and soil measurements}

Figure 6 shows a record of soil moisture recorded over several seasons within the Gully A channel and the Gully A fan. Each probe was installed at the ground surface, on top of the dry active layer; thus, all measurements are of surface soil moisture.
Three separate wetting patterns are observed: (1) seasons when moisture levels are low all summer (e.g. 2007-08 in Fig. 6); (2) seasons when diurnal wetting pulses occur in January and February (e.g. 2006-07 and 2009-10 in Fig. 6); and (3) one season when high soil-moisture conditions persist through all of December (and show no signs of drainage or evaporation at night) (2010-11 in Fig. 6, recorded on the Gully A fan as opposed to the channel, as the sensor and logger in the channel were destroyed during this season). Across these broadscale patterns, several seasons show evidence for brief, low-volume wetting events in early December (2006-07 and 2007-08). These data permit us to define the location, duration, abundance, geometry and relative importance of meltwater sources in gully systems.
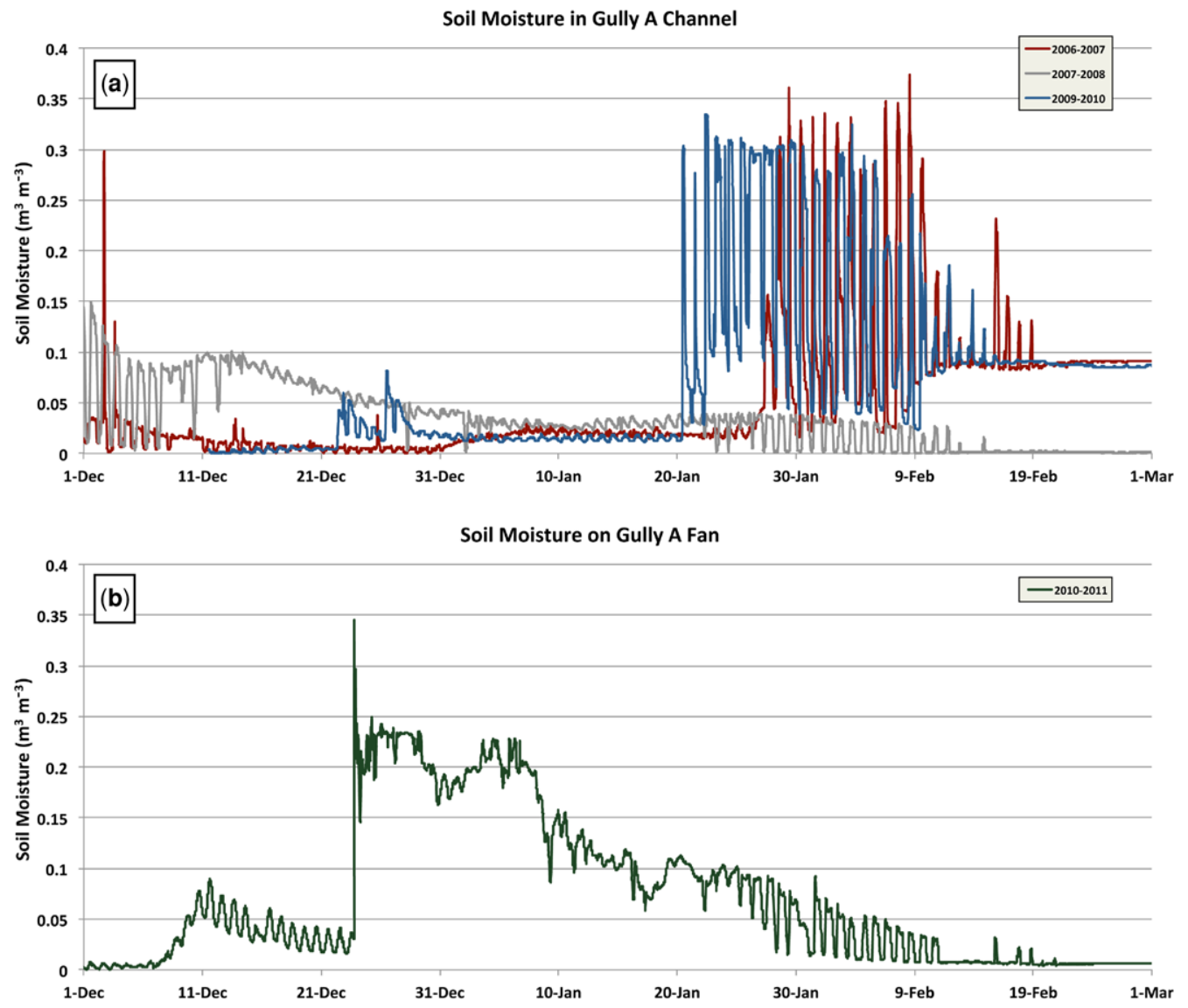

Fig. 6. (a) Soil moisture recorded within the active channel for Gully A, located within the primary alluvial fan on the floor of South Fork. Two primary phases of fluvial activity are observed: early-season melting of in-channel snowpacks and ice; and late-season diel pulses of meltwater. (b) Soil moisture as recorded on the fan for Gully A during the austral summer (December-February) of 2010-11. Saturation of the fan was significant enough that soil-moisture readings remained elevated through the 'night'. 


\section{Early-season flow}

Time-lapse imagery acquired during 2006-07, 200910 and $2010-11$ provide details regarding the precise nature of mid- to late spring ( $c$. December) overland flow events and the extent of erosion that they produced. Figure 7 and Supplementary material (SUP) video 1 are a time-lapse sequence acquired on the fan of Gully A in November, 2006, showing late-afternoon pulses of discharge across the fan. Fluvial activity in the fan is first expressed at the surface by wetting of the porous dry active layer, which lowers the albedo of the surface, and water propagates both downstream and laterally. This moistened soil associated with stream channels is the surface expression of the 'hyporheic zone', defined as the sediment surrounding a stream channel that interacts with the stream water (McKnight et al. 1999; Gooseff et al. 2002). Excavations within the hyporheic zone for Gully A show that meltwater flows first along the top of the ice-cemented soil (the ice table), typically found at $c .20 \mathrm{~cm}$ depth throughout South Fork (Fig. 8), a process that has been recently documented for water tracks in the
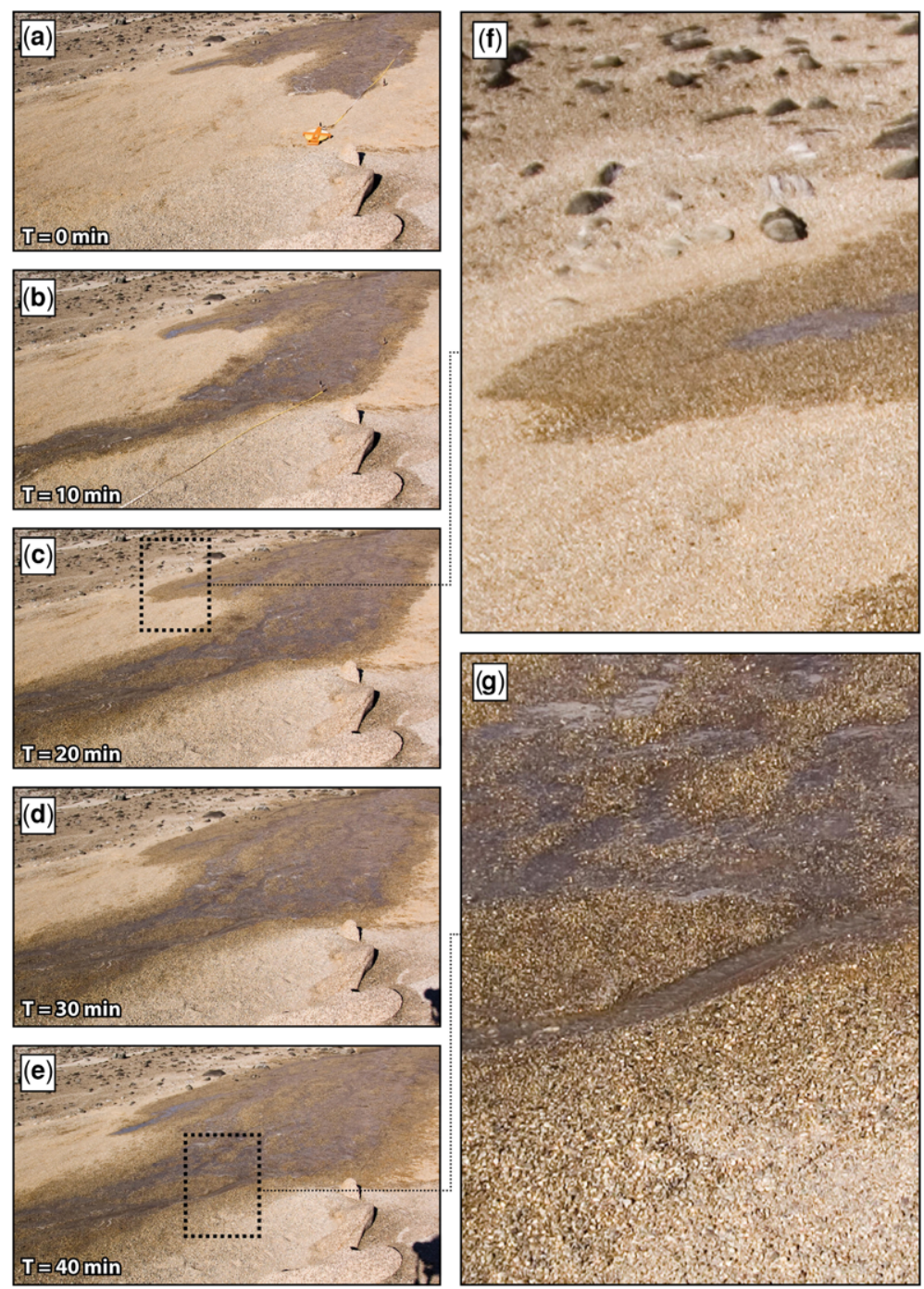

Fig. 7. Propagation of surface flow across the fan of Gully A on 28 November 2006, imaged at 10-minute intervals (a-e). High values of insolation produce diel pulses of flow across the surface and through the $c .20 \mathrm{~cm}$-thick active layer. Flow only persists across the surface once the surrounding pore space has been filled, which occurs both downstream and laterally (f). Small-scale incision occurs predominantly once soil saturation occurs, as seen in (g). 


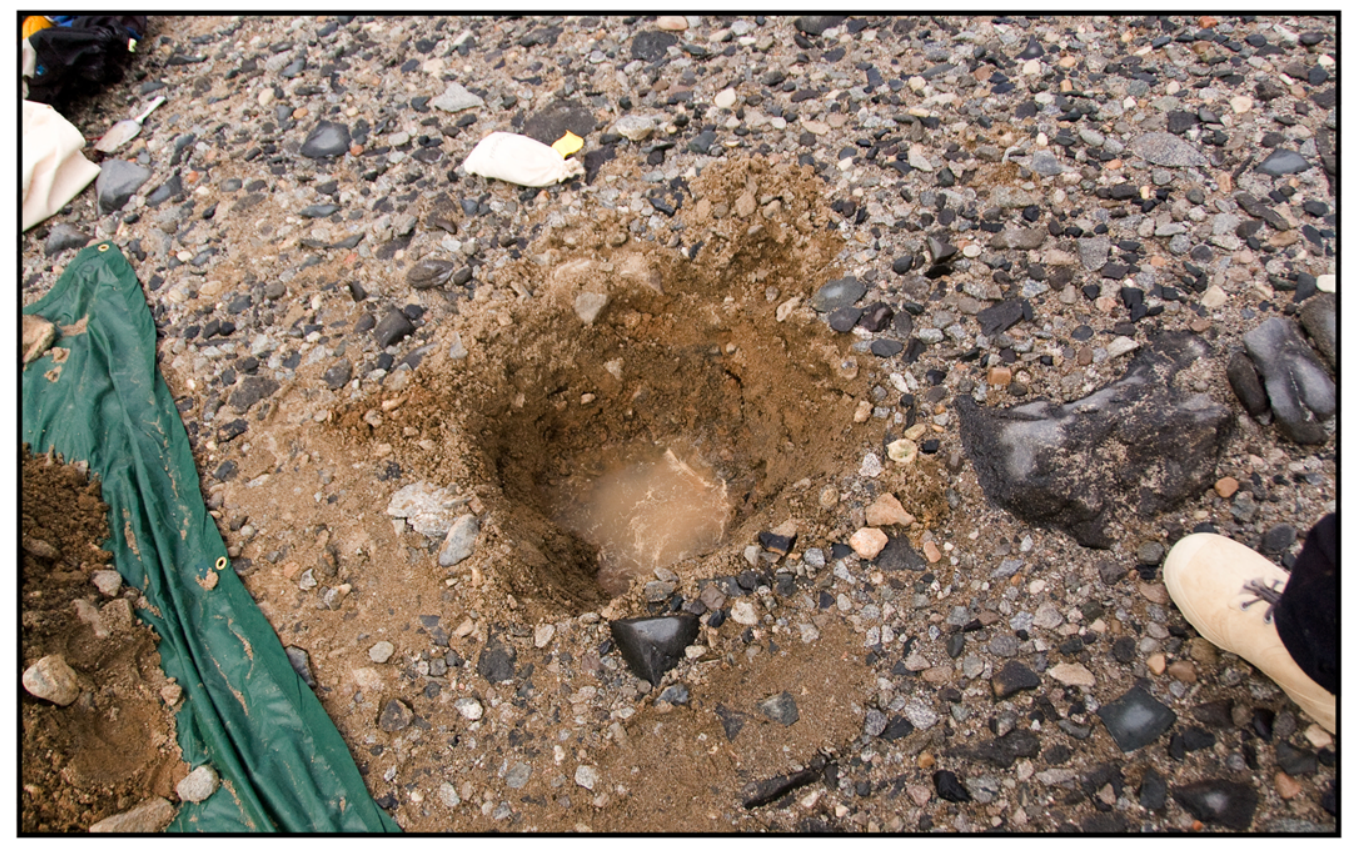

Fig. 8. Pit excavated from a water track in close proximity to the Gully A fan. Pit depth is $c .20 \mathrm{~cm}$. Immediately upon excavation, sediment-laden water exfiltrated from the upslope pit wall, filling the depression. Active layer groundwater flow continues to the floor of the valley, where it pools. Active layer drainage commonly reaches the valley floor before overland flow is established down the full length of the gully channel (see video 2 in the Supplementary material). Image acquired on 7 December 2006.

Dry Valleys (Lyons et al. 2005; Head et al. 2007; Levy et al. 2011, 2014; Dickson et al. 2013; Gooseff et al. 2013). When discharge exceeds the infiltration capacity of the soil, overland flow begins in the gullies. Sufficient discharge can initiate centimetrescale incision of the active layer (Fig. $7 \mathrm{~g}$ ).

\section{Summer flow}

Summer (January) surface runoff in Gully A (Fig. 6) was imaged in January 2010 (Fig. 9 and SUP video 2). Meltwater reached the break in slope on the valley floor (Fig. 2) in late December and continued to advance across the surface during diurnal discharge pulses (Fig. 9; SUP video 2). By 5 January 2010 (Fig. 9b), the meltwater reached a portion of the gully where the channel becomes less incised and metre-scale lateral expansion of the hyporheic zone occurred (Fig. 9c), similar in behaviour to earlyseason pulses (Fig. 7; SUP video 1). Generally warm and cloud-free conditions combined with the decreased infiltration capacity of the active layer (due to flow from earlier in the season) to allow the pulses to advance at an average rate of $8 \mathrm{~m} /$ day across the surface until 22 January, when it reached the damp floor of the valley, which had already been receiving meltwater through the shallow subsurface hyporheic zone (Figs 9d \& 10). This distal region of the gully system had already been saturated through early-season meltwater from surface snowpacks (Fig. 9a) and from shallow subsurface drainage along the top of the ice-cemented layer (the ice table) that preceded the surface flow observed here (Fig. 10).

\section{Late-season flow analysis and discussion}

Fluvial activity during late-season flow is diel (occurs once every $24 \mathrm{~h}$ ), due to the lower surface energy balance (reflected as cooler temperatures) while the floor of South Fork is in shadow at 'night'. The steep valley walls create high-amplitude insolation disparities and subsequent high-amplitude temperature ranges $\left(c .25^{\circ} \mathrm{C}\right.$ range during the peak season: Fig. 11). Thus, meltwater pulses that advance during the day and evening (Fig. 9; SUP video 3) freeze in-channel once the sun is behind the Asgard Range later in the day. The high-amplitude diel fluctuations of soil moisture derived from lateseason meltwater (Fig. 6a) are generated by this discharge pattern. A similar discharge pattern is seen 

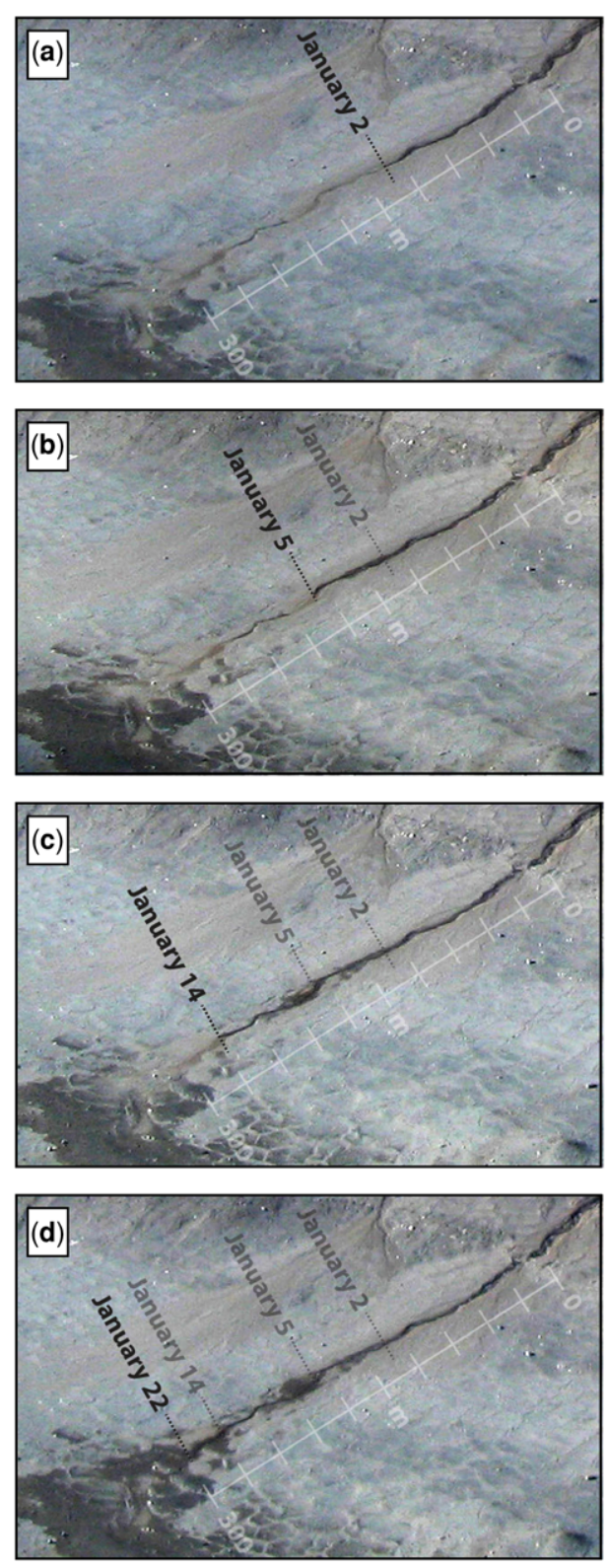

Fig. 9. (a-d) Surface pulses observable on the channel floor of Gully A through the course of January 2010 (the full sequence is available in video 2 in the Supplementary material). Pulses are diel and advance across the surface at an average of $8 \mathrm{~m} /$ day. Meltwater seeps on the valley floor are observed well before continuous overland flow reaches the floor on 22 January. Vantage point shown in Figure 4a (Site 1).

in Taylor Valley streams, where direct insolation on glacial surface generates daily discharge pulses (Conovitz et al. 1998).
For comparison, late-season activity was also observed in Gully B, where time-lapse observations from January 2013, recorded similar daily pulses of meltwater advancing across the alluvial fan (Fig. 12; SUP video 4). In this instance, earlymorning images on 11 January (03:49) show transient in-channel ice formation (Fig. 12d), which then remelts once high-insolation conditions return during the day.

During particularly warm austral summers (January-February), such as 2009-10, late-season discharge continues through January until continuous overland flow reaches across the alluvial fan for Gully A and onto the floor of the valley to an ephemeral pond on the floor of South Fork (Fig. 13; SUP video 5). Similar activity was observed for Gully B in the 2012-13 season (SUP video 4). Since the active layer on the floor of the valley is at this time already saturated by pooled baseflow, channel flooding rapidly extends across the floor of the valley, thus enlarging the pond (Fig. 13).

\section{Mid-season discharge}

On 8 December 2010, meltwater reached the break in slope (Fig. 2) that marks the beginning of the fan of Gully B (Fig. 14; SUP video 6). Since data collection began in November 2006, this was the first evidence of surface flow at the fan for Gully B that had been observed with field observations, soil-moisture sensors or time-lapse imaging. Surface wetting combined with deposition of sediment was initially focused on the west side of the fan (Fig. 14b; SUP video 6) but switched to the east after $c .3$ days, when diel discharge pulses were recaptured by the main channel and extended towards the floor of the valley.

After discharge was captured by the main channel, incision began and proceeded to erode the channel (Fig. 15) through loose fine-grained material within the active layer, followed by icecemented soil at depth. Incision during the following 7 days exceeded downcutting recorded during all previous and subsequent observations. Channel erosion reached a depth of $81 \mathrm{~cm}$ at the deepest point by 16 December 2010, across a channel c. $5 \mathrm{~m}$ wide.

A subsequent flooding event with unusual characteristics occurred at Gully A (Fig. 16; SUP videos 7 and 8) on 17 December 2010. During this event, a runoff pulse advanced across the fan of Gully A for a total of $c .260 \mathrm{~m}$ in 1 day, a rate $c .32$ times faster than what had been measured in 2009-10, when the flow front advanced at an average of $c .8 \mathrm{~m} /$ day. By 18 December, discharge reached the distal alluvial fan, where the two meteorological stations were located (Fig. 3) and where a time-lapse station had been installed (Fig. 4c, Site 3). Since the station 

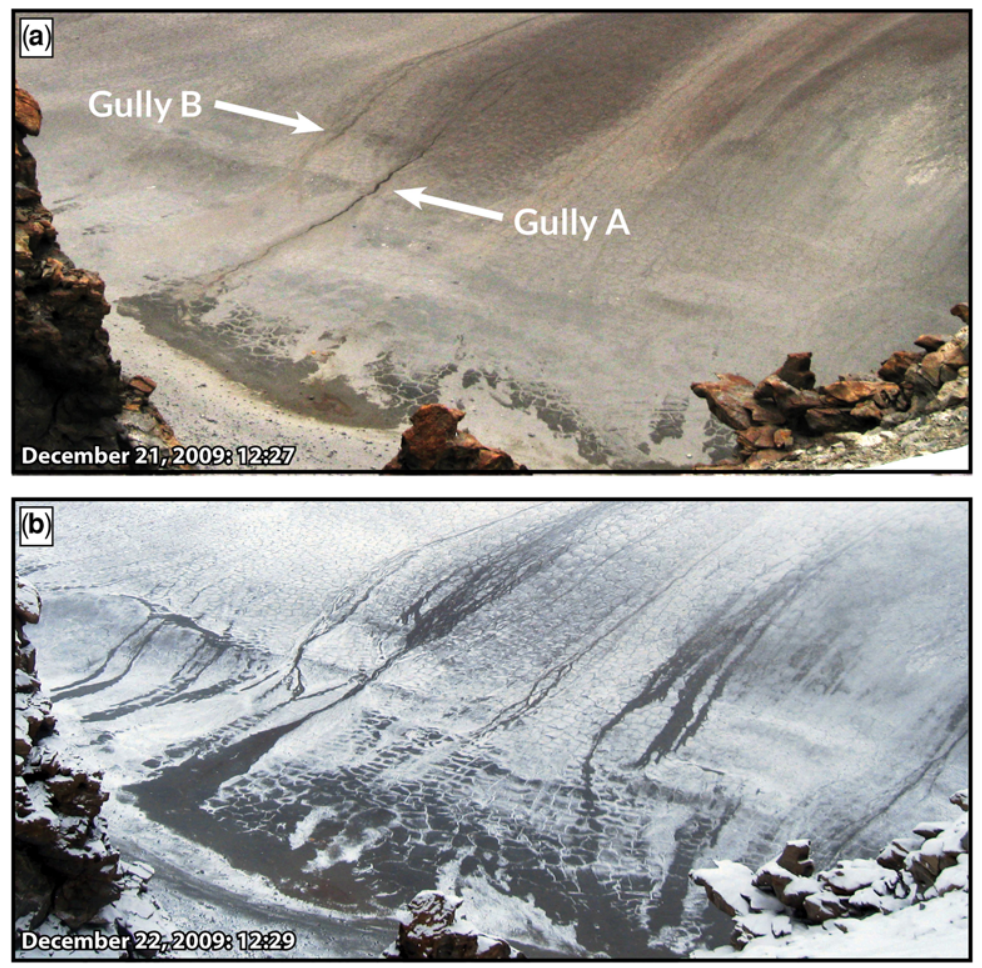

Fig. 10. Pair of images from (a) before and (b) just after an early-summer (December) snow event in South Fork. Snow was preferentially removed first from soils with elevated water content, which have an elevated heat capacity relative to neighbouring dry soils. Light/dark patterns in (b) reveal shallow groundwater flow within the channels and fans for Gully A and Gully B, and also in previously unrecognized drainage networks to the east and west. These networks feed water tracks on the floor of the valley that pond later in the season (see video 2 in the Supplementary material). Vantage point shown in Figure 4a (Site 1).

was installed on the alluvial fan instead of further upstream (like the observations above for Gully B), this allows for an assessment of fan emplacement during flood events (Fig. 17).

Water that reached this portion of the fan contained suspended sediments (Fig. 16b) and flows over a low-gradient surface. During peak-flood conditions (18-22 December), fan level aggraded by $c$. $10 \mathrm{~cm}$ at the centre-most point where flow was concentrated (Fig. 16f, g). Discharge pulses continued to advance across the fan and fill the pond on the floor of the valley, but deposition significantly outpaced incision at the camera location on the fan. Flow across the fan was observed in two distinct pulses every day: one high-energy and one low-energy. The high-energy pulses occurred late in the day $(c$. 18:30) and would last for $c$. $6 \mathrm{~h}$, after which flow would cease and standing water on the alluvial fan would freeze overnight (Fig. 16c; SUP video 8). The following morning, incident solar radiation would re-melt this ice to produce the diurnal lowenergy event.

\section{Mid-season discharge analysis and discussion}

On the floor of South Fork, the ice table (the top of the ice-cemented soil below the dry active layer) typically occurs at c. $20 \mathrm{~cm}$ depth (Fig. 8). This suggests that around three-quarters of the erosion from the event initiated on 9 December 2010 may have involved rapid removal of previously ice-cemented sediments. This layer was eroded by a combination of: (1) exposure to mid-day, peak-season insolation after the superposing sediments were removed; (2) mechanical erosion as floodwater pulses entrained sand from the ice-table surface; and (3) thermal erosion as the comparatively warm meltwater came into contact with the still-frozen permafrost table, advecting heat into the alluvial fan.

Soil-moisture readings on alluvial fans can be used to distinguish between high-energy events, like those documented in 2010-11, and the lowenergy diel pulses that characterized 2006-07 and 2009-10 (Fig. 6). During a low-energy season, 
Surface Temperature (Valley Wall)
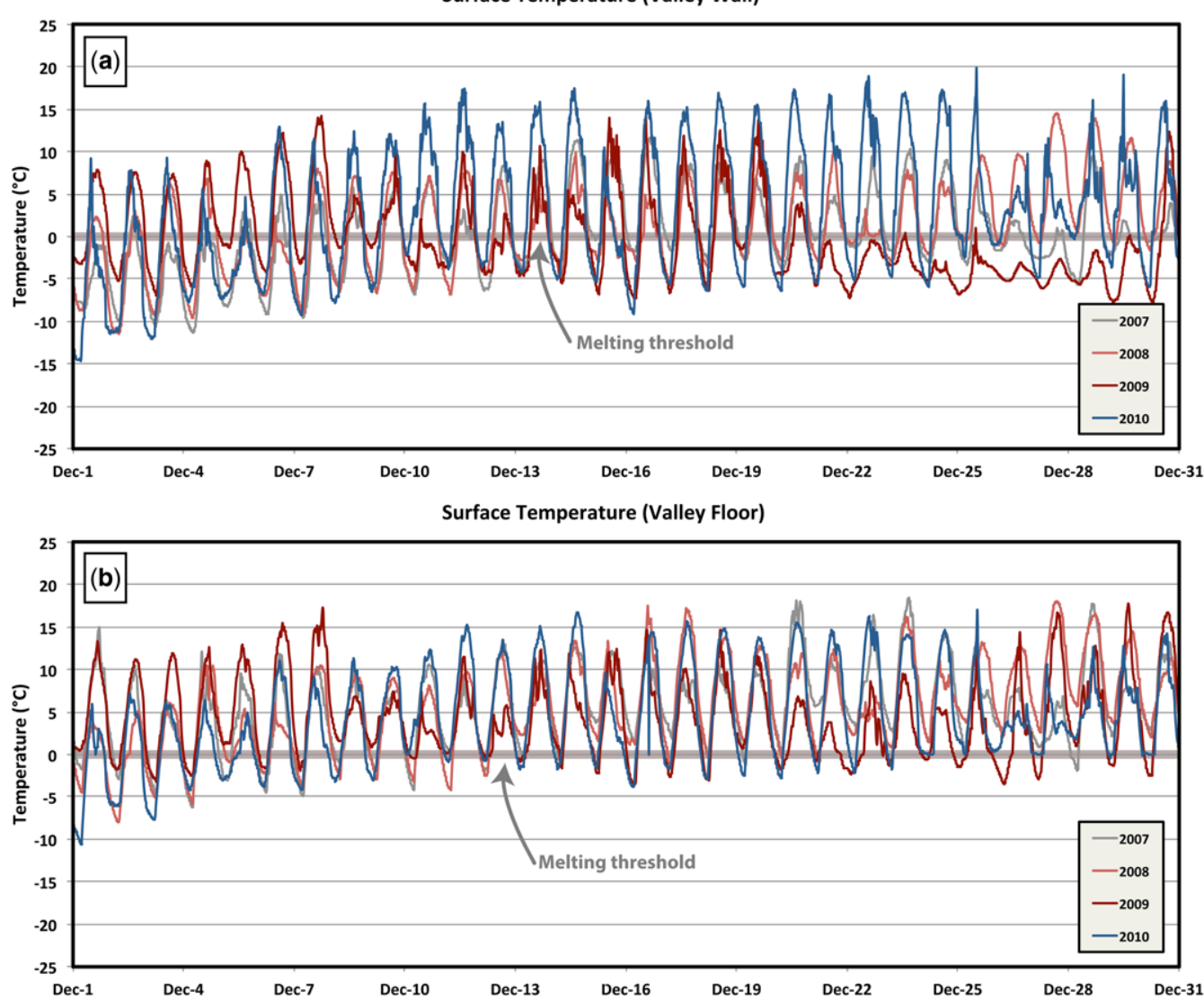

Fig. 11. Surface-temperature records for the valley wall (a) and the valley floor (b). December 2010 was within the range of typical temperature conditions of previous seasons.

alluvial-fan surfaces are exposed to diel pulses of meltwater, but that meltwater is low in volume and infiltrates, evaporates or freezes/sublimates at the surface before the following day's pulse arrives. This creates high-amplitude soil-moisture readings during these seasons (Fig. 6a), but infiltration and evaporation are high enough that some thickness of the dry active layer must be resaturated every day before surface runoff occurs.

In contrast, during flood events like 9 December 2010, the volume of meltwater delivered to alluvial fans is sufficient to persist through Antarctic 'night' during the peak season, such that soil-moisture readings stay elevated (Fig. 6b). Shallow groundwater flow (and attendant soil-moisture readings) decrease gradually after overland flow has ceased. Thus, we define 'flood' conditions at this site to be when nighttime soil-moisture readings remain elevated relative to readings taken before the surface pulses arrived (Fig. 6b).

\section{Water sources}

A variety of water sources are available to these gully channels. Here, we attempt to assess their relative contributions to gully channel activity in the context of the discharge patterns described above.

\section{Groundwater}

Through extensive field observations, we did not encounter any evidence for contributions to gully activity from deep groundwater aquifers, lying below the extensive, c. $350 \mathrm{~m}$-thick permafrost layer (Bockheim \& Hall 2002).

\section{In-channel, wind-blown snow}

Intense drainage winds that emanate from the polar plateau and funnel through South Fork in the winter (Nylen et al. 2004) mobilize surface snow 

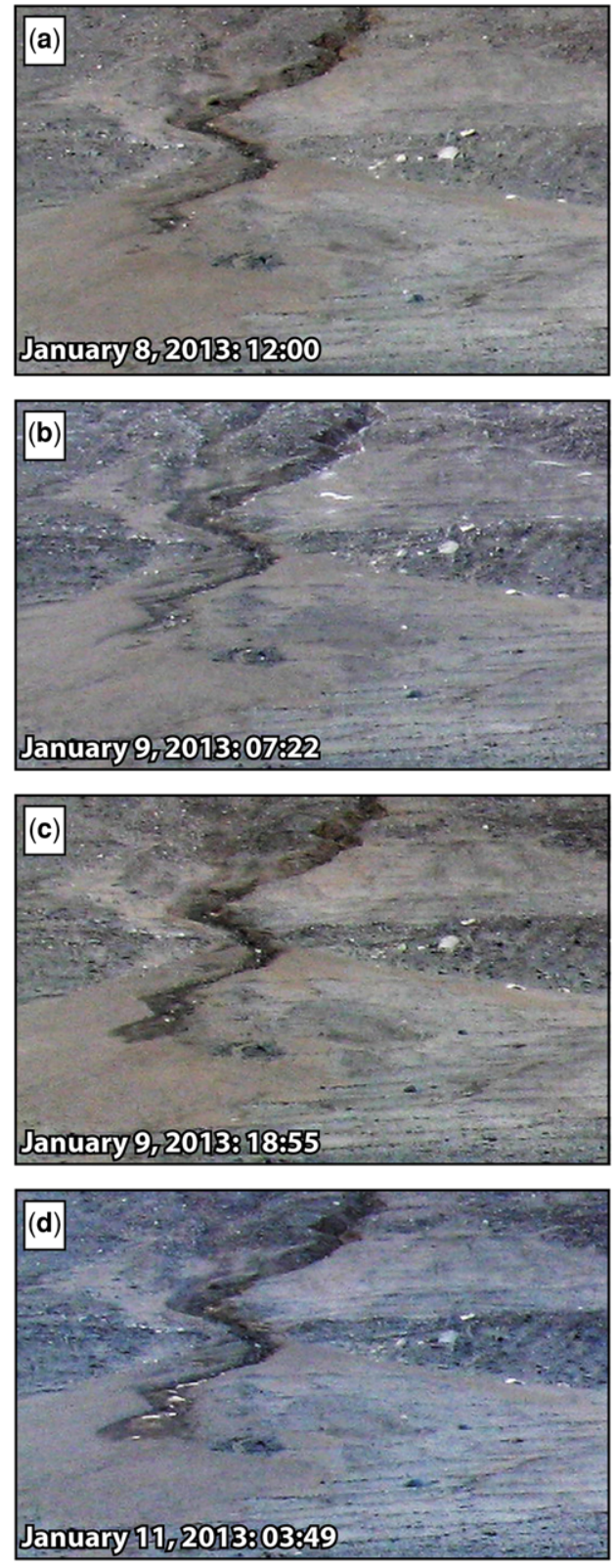

Fig. 12. (a-d) Late-season discharge observed on the fan of Gully B in January 2013, imaged over the course of three days. Pulses extend to the fan on 8 January, but no further advance occurred as subsequent cloudy conditions during the remainder of the season limited runoff generation. Vantage point shown in Figure 4b (Site 2).

and redistribute it preferentially in topographical traps such as gully channels (Fig. 18). Thus, despite average annual precipitation of between 7 and $82 \mathrm{~mm}$ measured at nearby Lake Vanda (Thompson
1973), gully channels in South Fork can accumulate snowbanks of the order of $1 \mathrm{~m}$ in thickness and tens to hundreds of metres in length (Fig. 18a).

These surface snow deposits melt in diel pulses as insolation increases on the floor of the valley in mid- and late spring (November). This reservoir is typically depleted by early to mid-December (Figs 6a \& 18). In particularly dry winters, like 2010 (Fig. 6b), moisture sensors on both alluvial fans do not record any early-season runoff, suggesting that there was not enough source snow to produce streamflow.

\section{Summer-season snowfall}

Occasional snowfall events occur during austral spring and summer (October-March), providing another source of surface meltwater. One notable storm occurred during the week of 22-28 December 2009 , with the deposition of $c$. $1-2 \mathrm{~cm}$ of snow. Snowfall on the valley floor and wall permits an assessment of the hydrological contribution of fresh snow to gully activity. Soil-moisture readings within the channel for Gully A recorded this event and the diel melting that ensued (Fig. 6a). While these soilmoisture pulses were detectable, they are minor when compared to all other hydrological events within the gully (e.g. streamflow). Unlike conditions during the winter, snow that is deposited during austral spring or summer (October-March) sublimates quickly, not allowing for a volumetrically significant accumulation of snow or its conversion to meltwater. Thus, summer-season snowfall is considered a minor contributor to gully discharge in South Fork.

\section{Melting of ice-cemented sediments}

The dry active layer through which meltwater flows in South Fork gullies is bounded by an aquiclude of ice-cemented sediment at $c .20 \mathrm{~cm}$ depth. The pervasiveness of this unit makes it a volumetrically significant source of water in the vicinity of both Gully A and Gully B. A temperature probe installed at $20 \mathrm{~cm}$ depth permits an assessment of when the melting isotherm reaches this depth (Fig. 19).

Thaw seldom penetrates to the $20 \mathrm{~cm}$ mark in fan sediments until early January, as observed in 200607, 2008-09 and 2009-10. Once thaw occurs, daily thermal cycles created by heat from high midday insolation propagating to depth through wet sediments is recorded. Large daily temperature swings in thawed sediment are in marked contrast to the smaller diel temperature oscillations that precede thawing and saturation of the base of the dry active layer. This may result, in part, from insulation of the fan ice cement by initially dry sediments, which become more effective at conducting and convecting heat when wetted (Levy \& Schmidt 2016). 


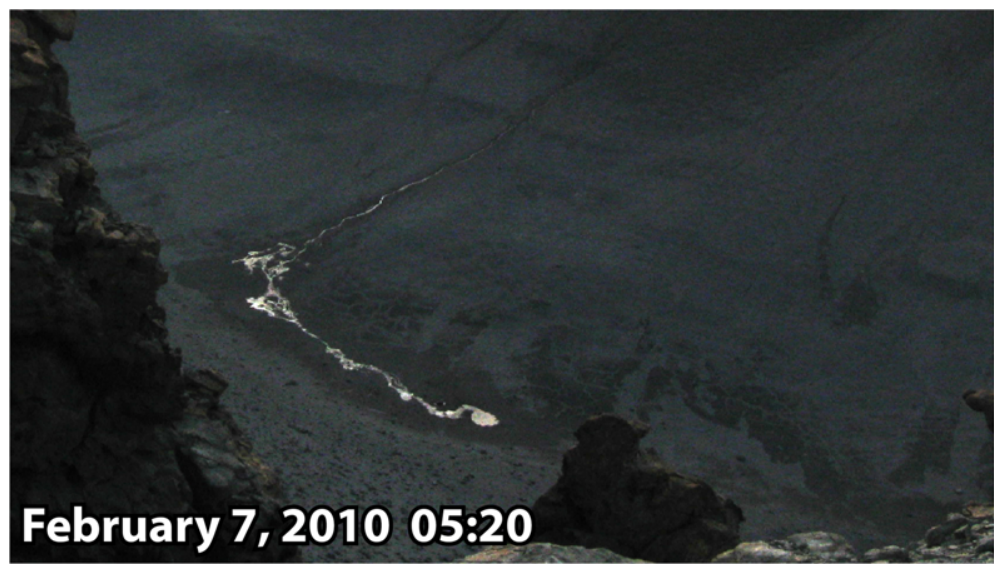

Fig. 13. Flow within Gully A during the end of austral summer 2010. Surface pulses continue into early February, eventually contributing to a small pond on the floor of the valley. Illumination intensity on the floor of the valley decreases through February due to the shadow cast by the Dais. During this time, melting is still possible along the valley wall. We infer that this mechanism generates ice reservoirs stored on the channel floor in the channels lower reaches (see Fig. 20). Vantage point shown in Figure 4a (Site 1).

Temperatures remain above $0^{\circ} \mathrm{C}$ at the $20 \mathrm{~cm}$-depth table through the course of January, which is likely, in part, to be influenced by warm meltwater advecting through the alluvial fan as part of the saturated active layer (Fig. 8).

The precise volume of meltwater generated from melting of the ground ice in the channel and fan is challenging to ascertain, but it appears to be a lateseason (late January) contributor that is enhanced in years when higher volumes of meltwater are being transported along the top of the ice table from upstream, as described below. Because segregation ice and massive ice are not found in the channel, the maximum volume of meltwater that can be seasonally drained from frozen soil is equal to the volume of the pore space (c. 30-40\%) (McKay et al. 1998). While the channels could funnel melted ice cement from adjacent terrain as well, this appears to be minimal in its erosional influence due to the lack of soil-moisture pulses in otherwise warm years, such as 2007-08 (Fig. 6a).

\section{In-channel ice reservoirs}

The banks of gully channels in their distal reaches sometimes host deposits of snow and clean ice buried by a $c .10 \mathrm{~cm}$ layer of aeolian-derived finegrained sediment (Fig. 20). These ice deposits can be as much as $80 \mathrm{~cm}$ in height and $c .1 \mathrm{~m}$ deep from the channel wall to the channel floor, and extend for several metres down the length of the channel. The amount of buried ice varies from season to season, with the largest volumes documented in November 2006 (Fig. 20), while a similar survey in November 2009 revealed only small, isolated patches. By the time field observations began in late November of 2006, the melting isotherm had penetrated through the thin sediment cover, and fractures appeared in the overlying layer (Fig. 20). All in-channel ice was depleted by mid-December 2006.

\section{Alcove snowpacks}

The most volumetrically significant ice unit at the surface of both Gully A and Gully B are perennial snowpacks found in their respective alcoves. In situ observations have shown that these snowpacks begin melting in early December, consistent with when surface temperatures on the valley wall and in the alcove itself surpass the melting point (Fig. 11). The dirty snowpack within the alcove of Gully A is extremely well dissected by fluvial drainage networks (Fig. 5), implying sufficient overland drainage to carve channels.

Despite commencing peak-season melting in late spring (November-December), runoff from these sources were not recorded on the alluvial fan until late January in 2007 and 2010 (Fig. 6a). The lack of activity recorded in 2008 suggests that in some years melting is insufficient to reach the middle of the fan of Gully A as overland flow. Below the dry active layer (Head \& Marchant 2014), however, meltwater does flow along the top of the ice table as water tracks (Fig. 8) and reaches the valley floor, where it wicks to the surface to produce 'wet-top' polygons (Levy et al. 2009) and ponding.

Water track-style discharge is seen most clearly in Figure 10 (SUP video 3), when a relatively long- 

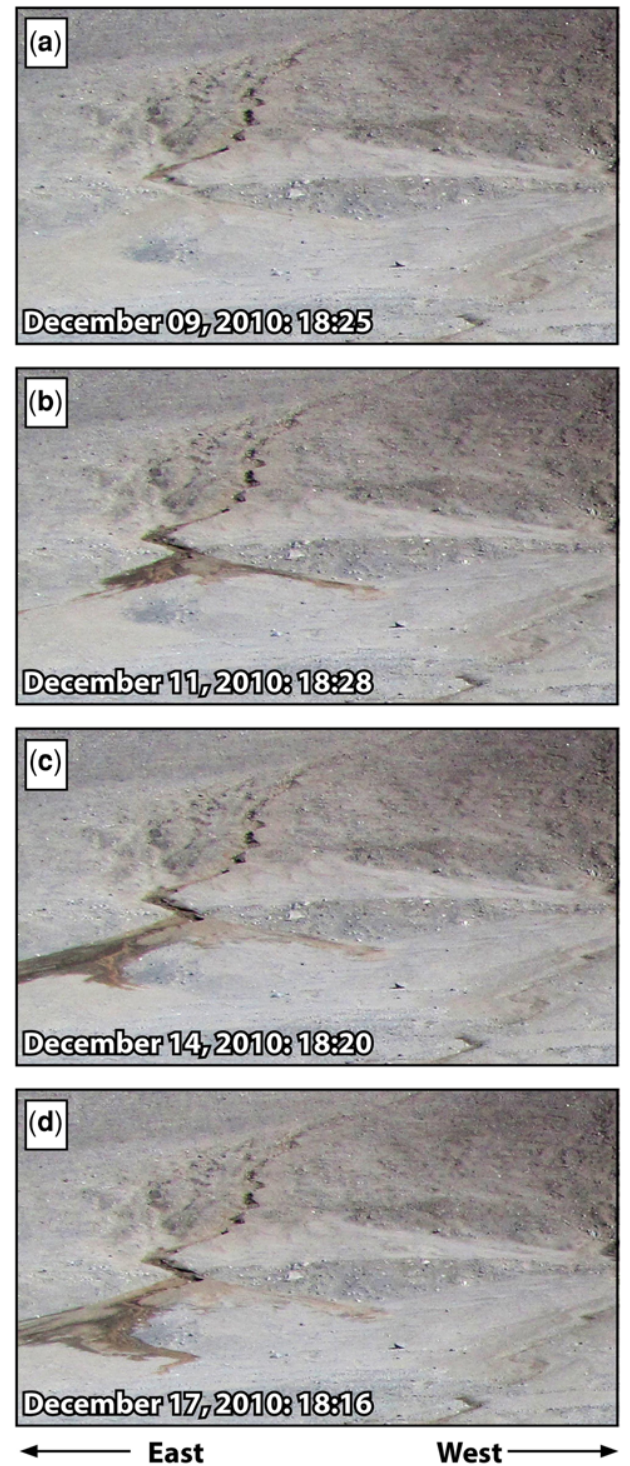

Fig. 14. (a-d) Time-lapse sequence of early-season activity within Gully $\mathrm{B}$, imaged over the course of one week. Vantage point shown in Figure 4b (Site 2).

High-discharge diel events cause incision of the channel at a rate of $c .1 .6 \mathrm{~cm} \mathrm{~h}^{-1}$ during hours when flow occurred. This resulted in $81 \mathrm{~cm}$ of channel incision over the course of 6 days.

duration snowstorm, described above, on the summer solstice of 2009 provided a thin layer of snow across the floor and the southern wall of South Fork. As the thin layer of snow began to ablate, soils with an elevated water content (and thus heat content) compared to neighbouring soils, experienced an increased sublimation/melting rate.
High-frequency time-lapse observations (Fig. 10; SUP video 3) during this event enabled mapping of water tracks and in-channel baseflow. Water appeared to be present in the sediments of both Gully A and B's channels several weeks before surface discharge was recorded on the alluvial fans. For Gully A, apparent wetting extended across the alluvial fan to the valley floor and to the ephemeral pond to the west. Shallow meltwater present in Gully B apparently terminated within the alluvial fan.

This snow event also revealed shallow meltwater activity within neighbouring water tracks that have no surficial channels, such as the dendritic networks observed to the west of Gully A (to the right in Fig. 10). These water tracks emanate from higher elevations along the valley wall, and are connected in their distal reaches with the valley thalweg (Fig. 10; SUP video 3). Several of these water-track networks terminate at an ephemeral pond informally termed 'VXE-6' pond. This pond lacks surface input channels, so these observations suggest that the floor of South Fork (including the distal portions of Gully A and Gully B, and the nearby Don Juan Pond: Dickson et al. 2013) is linked by water-track flow through the thalweg of the valley (Dickson et al. 2013).

\section{Water sources discussion and synthesis}

What conditions produce in-channel ice reservoirs and account for the distribution of fluvial and groundwater features in South Fork? Wright Valley as a whole, and South Fork specifically, are eastwest trending, such that the north-facing wall annually receives significantly more insolation than the shaded south-facing wall (Marchant \& Head 2007). This north-south asymmetry is likely to be the primary cause of the disparity between fluvial features on the north-facing wall v. the lack of fluvial features on the south-facing wall.

Surface-temperature records reveal that for several weeks every austral spring (October-November) and autumn (March-April), conditions on the southern, equator-facing wall are not only warmer than the northern wall but also warmer than the floor (Fig. 21), due to the shadow of the Dais being cast over the floor (Figs $22 \& 23$ ). At each equinox, the entire floor of the valley is in shadow (Fig. 23), while the valley wall is still illuminated during peak daytime conditions. In austral spring (OctoberNovember), any meltwater generated on the valley wall will freeze as it flows into colder sediments located downstream. Likewise, end-of-summer meltwater in February will also freeze in-channel, where it will then be buried by aeolian-transported sediment in the winter (Fig. 20). Thus, under sufficiently 


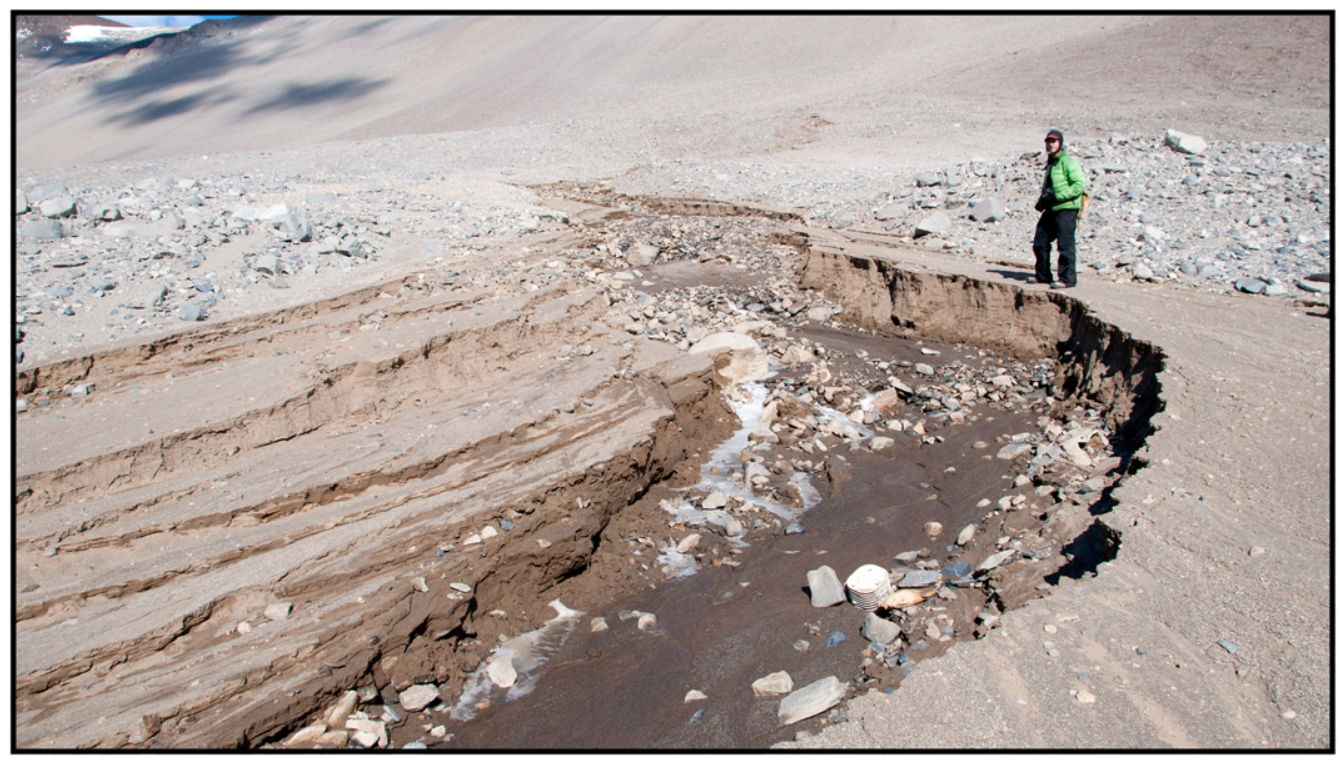

Fig. 15. Image of incision through the fan of Gully B, acquired on 16 December 2010. All incision occurred after flood conditions began on 9 December. The full time-lapse sequence is available as video 6 in the Supplementary material.

warm late-austral summer (February-March) and austral spring (October-November) conditions, concentrated in-channel ice reservoirs can be generated in proximity to alluvial fans (Fig. 20).

\section{Conditions required for net gully channel erosion}

The observations presented above show that gully channels are only one manifestation of downslope transport of liquid water in the Inland Mixed Zone of the Dry Valleys. The thermal response of soil to snowfall reveals a denser population of near-surface drainage systems in South Fork than had been previously documented (Fig. 10). Yet, if water is draining through the active layer in several locations, what is required for that drainage to erode a channel? More specifically, what is required for that drainage to erode a channel that is not erased by subsequent aeolian sedimentation (net channel erosion over inter-annual timescales)?

Observations from repeat site visits from 2006 to 2015 show that the volume of sediment lost from channel incision through alluvial-fan deposits was replaced by winter-transported aeolian sediment in all instances except for the December 2010 incision event. Evidence for aeolian emplacement of sediments in winter comes from observations of wellsorted, fine-grained sands filling the gully channels, coupled with an absence of observations in the channel soil-moisture records or time-lapse observations of any discharge events of a magnitude capable of mobilizing and emplacing several centimetres of sediment. Further, surficial modification of the active layer due to disturbance from our fieldwork each season (e.g. footprints, helicopter skid imprints, tent imprints) were significantly muted or erased entirely by the following season.

Considered over the entire observational period, typical discharge patterns appear to be dominated by late-season arrivals of meltwater from alcove snowpacks (Fig. 6). Channel switching, coupled with highly episodic flow, makes gauging the precise discharge volumes of these gullies difficult; however, the time-lapse imaging and soil-moisture data we present here suggest that typical late-season (January discharge only) flow is generally insufficient to incise channels deeply enough that the channels are preserved after winter aeolian deposition. Likewise, typical season discharge only minimally adds sediment to the alluvial-fan surface, resulting in little overall deposition of sediment on the fan (indeed, many 'typical' years see flow arrest high on the fan slope, allowing sediment to only refresh the fan surface near the apex).

Net erosion of gully channels only occurred during the anomalous flood event of December 2010 (Fig. 6b). The $c$. $80 \mathrm{~cm}$-deep, $c$. $5 \mathrm{~m}$-wide channel carved into the fan of Gully B (Fig. 14; SUP video 6) provided a reset point from which to measure the rate of refilling of gully channels by aeolian- 

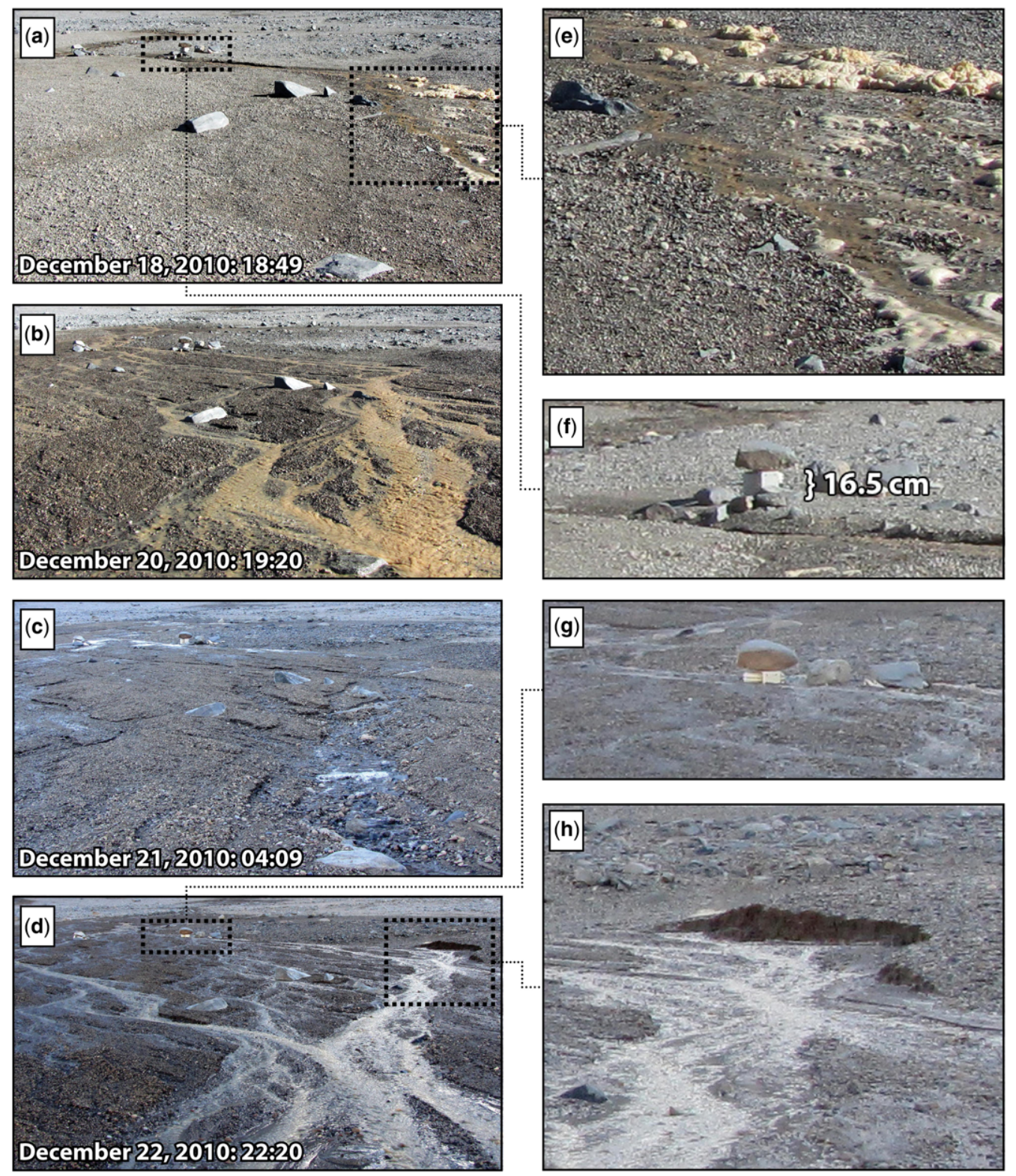

Fig. 16. Flood conditions on the fan for Gully A, imaged during four separate pulses over five days (a-d). Initial flow on the fan eroded small channels (e) but the fan aggraded over $10 \mathrm{~cm}$ through the entire event (f-g), while the fan experienced lateral erosion (h). The initial surface pulse advanced over $260 \mathrm{~m}$ on 18 December, more than 32 times the rate of the typical late-season diel pulse. Vantage point shown in Figure 4c (Site 3). The full time-lapse sequences are available as videos 7 and 8 in the Supplementary material.

deposited sediment. Channel depth at this location 5 years after the flood event, as measured in December 2015 , was $70 \mathrm{~cm}$, yielding a sediment-filling rate within the channel of $c .2 \mathrm{~cm} \mathrm{a}^{-1}$ at the top of the fan of Gully B, c. $200 \mathrm{~m}$ from the valley floor. The channel carved in December 2010 still controls flow direction within the gully at this location. Given the extremely steep slope of the western wall of this channel (near vertical in most places: Fig. 15), erosion of this wall by gravitational slumping is likely to occur during non-flood events (or even during high winds), meaning that not all channel 

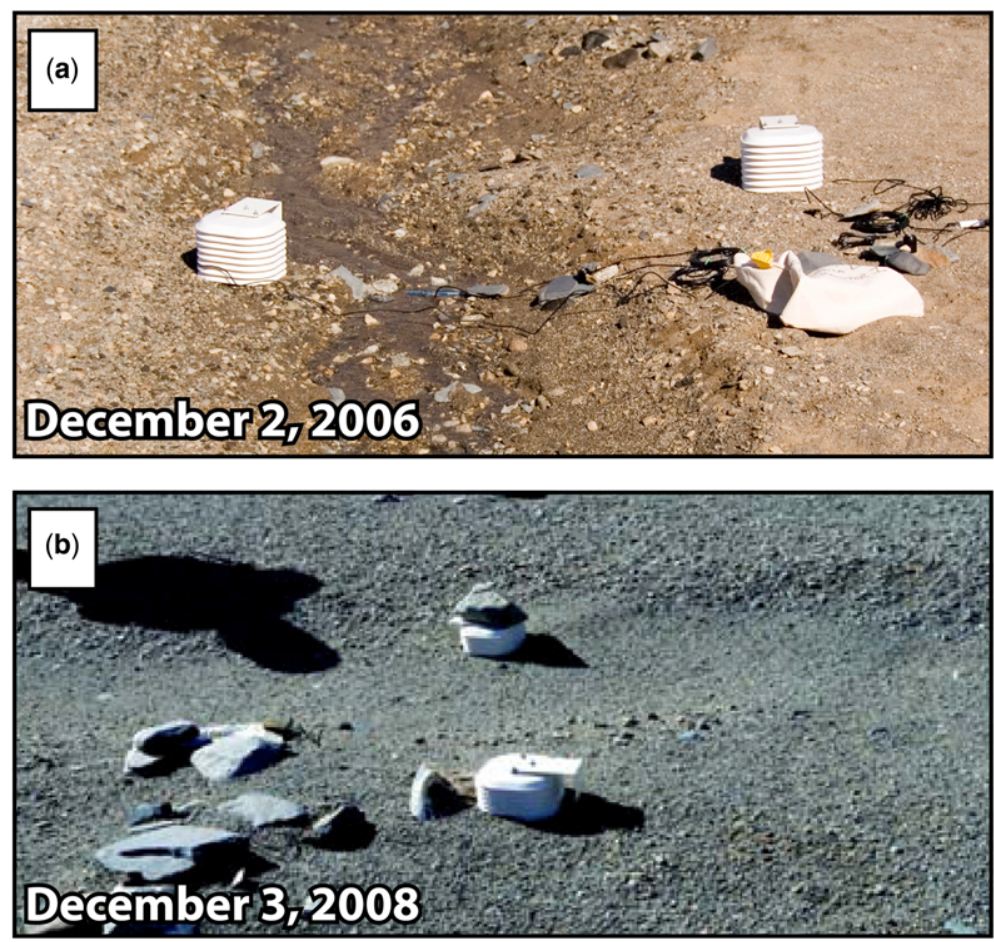

Fig. 17. (a) Flow within the channel for Gully A on 2 December 2006. Note the two radiation shields, part of the meteorological station network, on opposite sides of the channel for scale $(c .20 \mathrm{~cm}$ across). (b) Image of the same location taken 2 years later on 4 December 2008. Minimal evidence of recent streamflow is observed. The entire channel that was eroded in 2006 had been filled by aeolian-derived sediment.

modifications are directly associated with episodes of downchannel fluvial transport; subsequent masswasting processes are likely to act to widen and infill channels.

Based on these observations, we conclude that long-term erosion of gully channels in South Fork, under current conditions, is caused by punctuated flood events instead of the long-term succession of late-season pulses during 'typical' austral summers (January-February). Flood events, like those observed at Gully A and Gully B during December 2010, remove enough material in gully channels to compensate for the subsequent filling of gully channels by aeolian sedimentation during winter drainage wind storms, while inter-annual evidence for no-flood discharge is entirely erased every winter.

What climatic and hydrological conditions lead to discharge patterns like those that led to the December 2010 flood? While temperatures were warm during early and mid-December of 2010, and almost always above freezing on the valley floor (Fig. 11), they were not significantly outside the range from previous years when flooding was not observed, and are frequently lower with regard to peak daytime temperatures (Fig. 11b). Temperatures along the valley wall, where the meltwater is likely to have been sourced, are also within the range of previous season readings.

Conditions during November 2010, however, were exceptionally warm in South Fork along the valley wall (Fig. 24a), particularly during the first half of the month. From 8 to 14 November, peak temperatures along the valley wall were at least $7^{\circ} \mathrm{C}$ warmer than the previous peak temperature for that day in the three preceding seasons. Of the 120 November days from 2007 through 2010 , the nine warmest days and 13 of the 16 warmest days all occurred in 2010 . The peak temperature of $13.9^{\circ} \mathrm{C}$ was achieved on 12 November at $14: 30$.

Synchronous surface-temperature measurements collected on the valley floor for November 2010 do not show this unusual warming (Fig. 24b). Peak daytime temperatures from 8 to 14 November, when the valley wall was extremely warm, are consistent with measurements from previous seasons and are frequently lower than previous seasons (Fig. 24b). This disparity between high temperatures on the valley wall and low temperatures on the valley 

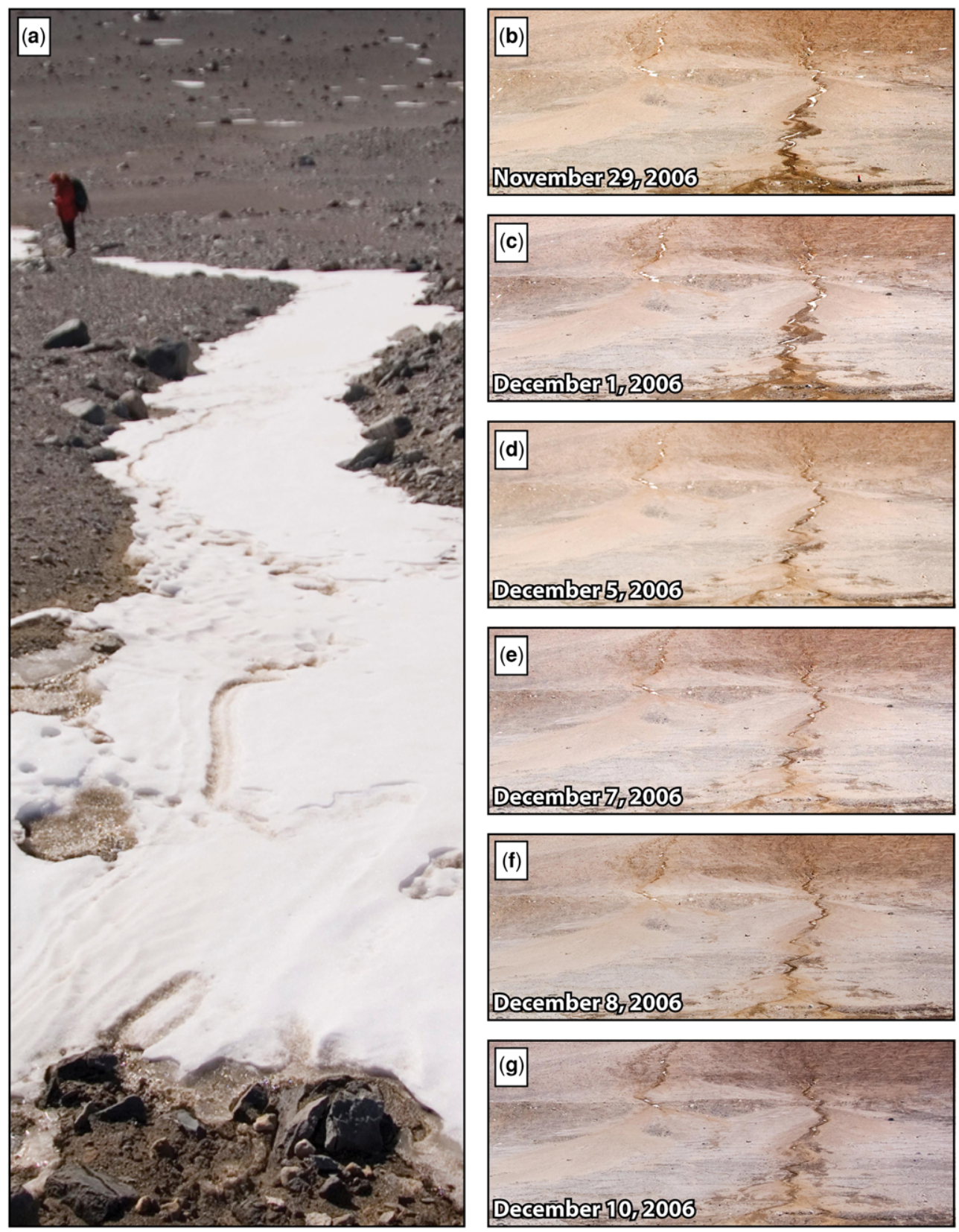

Fig. 18. (a) Field image of the channel of Gully A looking upslope on 29 November 2006. This sinuous snowbank is observed from a more synoptic viewing angle in (b). (b)-(g) Sequence of images showing the gradual late-spring (November-December) removal of in-channel ice and snow deposits from Gully A. This is in addition to buried ice that forms late in austral summer (February-March) and is then sheltered by wind-blown sediment (Fig. 20). This supply is depleted by early December. Vantage point shown in Figure 4b (Site 2).

floor is likely to result from shadowing caused by the steep walls of the Dais (the northern valley wall of South Fork), as described earlier.
While shadowing from the Dais results in warmer valley-wall surface temperatures than valley-floor surface temperatures every year, what sets 2010 
Temperature at Ice-Cement Table (20 cm Depth)

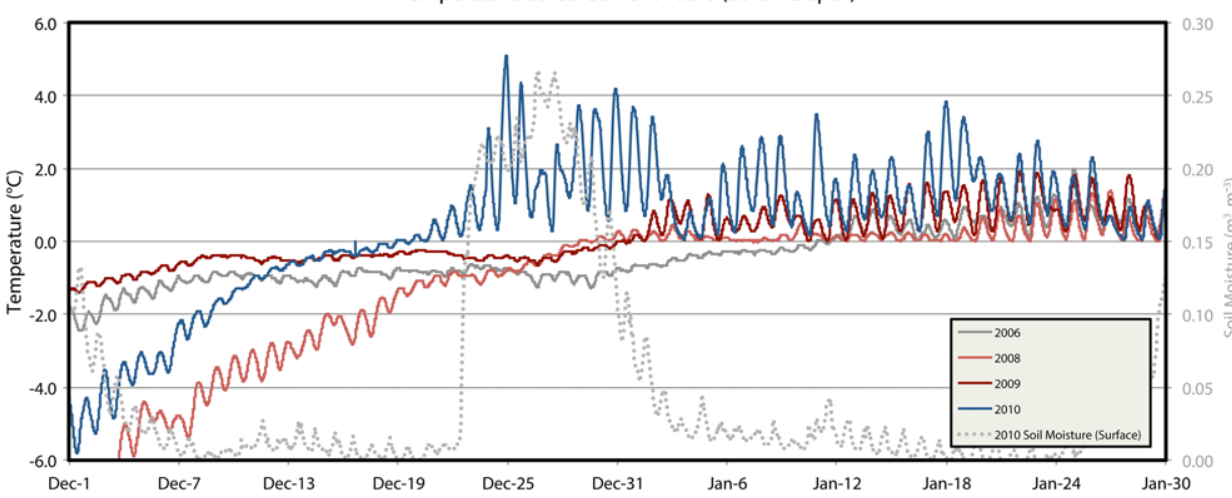

Fig. 19. Subsurface temperature and soil-moisture measurements at $20 \mathrm{~cm}$ depth within the alluvial fan for Gully A.
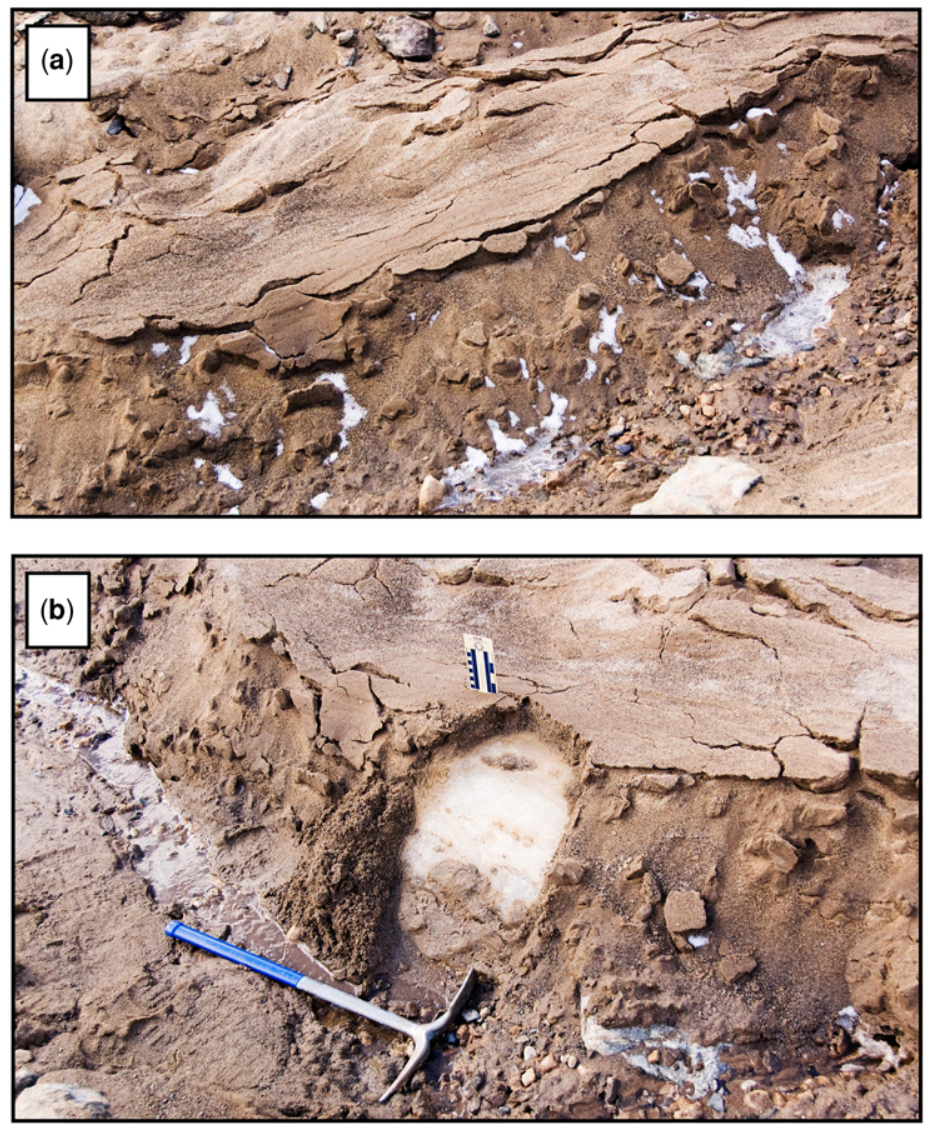

Fig. 20. (a) Fractured sediment cover over massive ice along the banks of the channel of Gully A. The unit is concentrated along the eastern channel wall, which is sheltered from morning insolation by the wall itself. (b) Image showing clean ice beneath the $10 \mathrm{~cm}$ sediment cover. With the channel itself representing the $x$-axis, ice is $c .75 \mathrm{~cm}$ in height along the $z$-axis, $c .1 \mathrm{~m}$ in depth from the channel wall towards the floor on the $y$-axis. Similar in-channel ice reservoirs were common during the austral spring (November) of 2006, and contributed to early-season melting at the gully channel/fan transition. Both images acquired on 10 December 2006. 


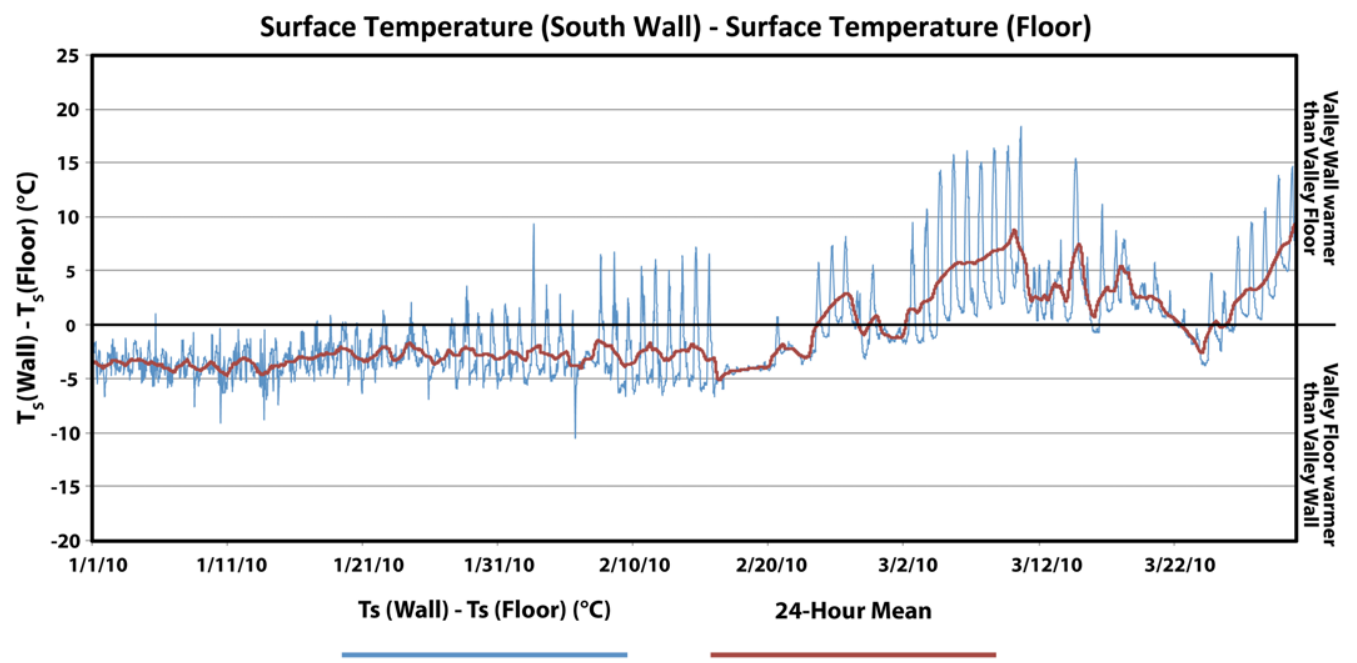

Fig. 21. Difference between the temperature on the valley wall and on the valley floor during late-season time periods. Later in austral summer (February-March), the shadow of the Dais causes cold conditions on the floor of the valley relative to the illuminated valley wall.

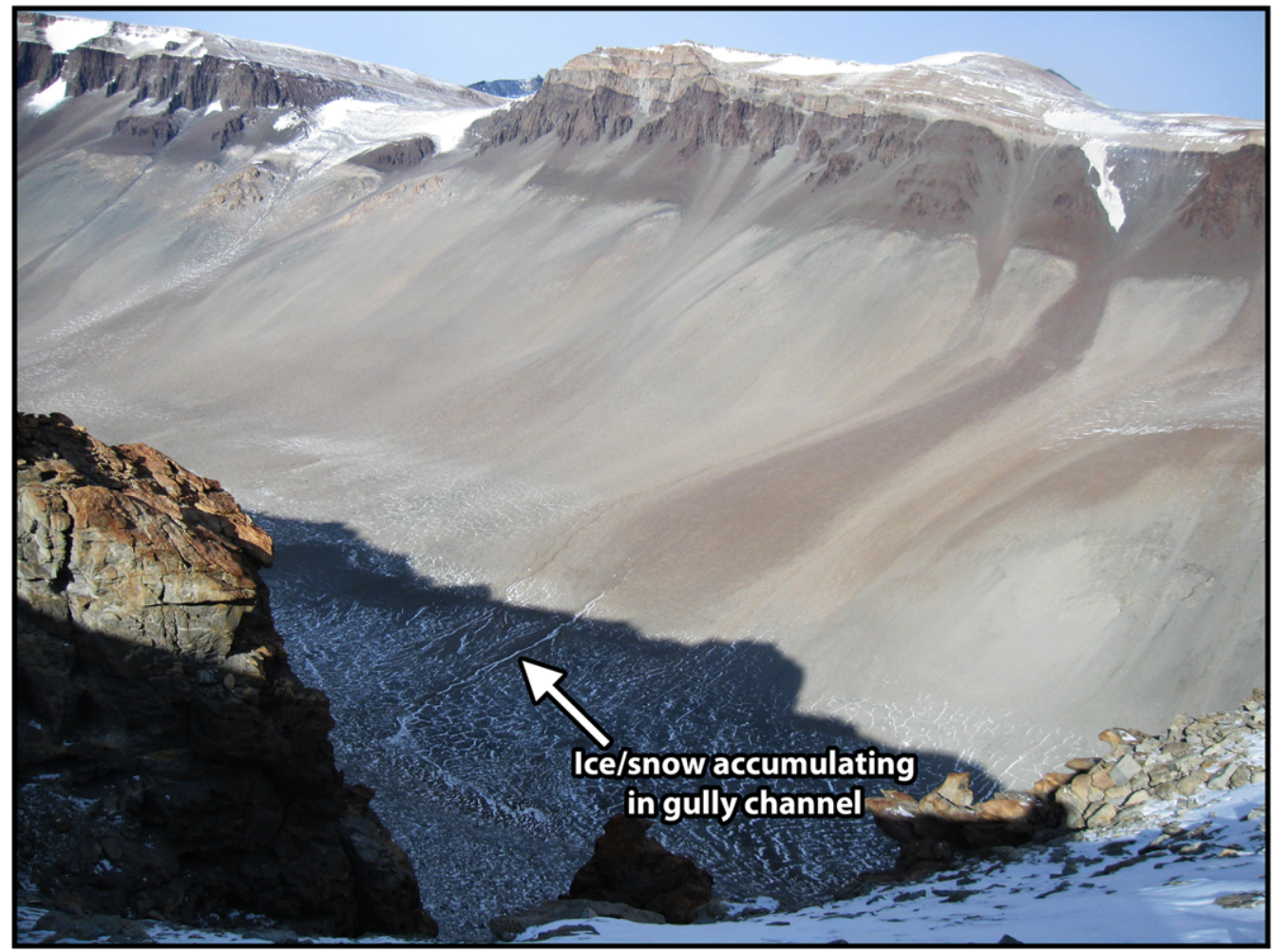

Fig. 22. Ice and snow preserved on the channel floor for Gully A. Image acquired on 2 March 2010. Vantage point shown in Figure 4a (Site 1). 

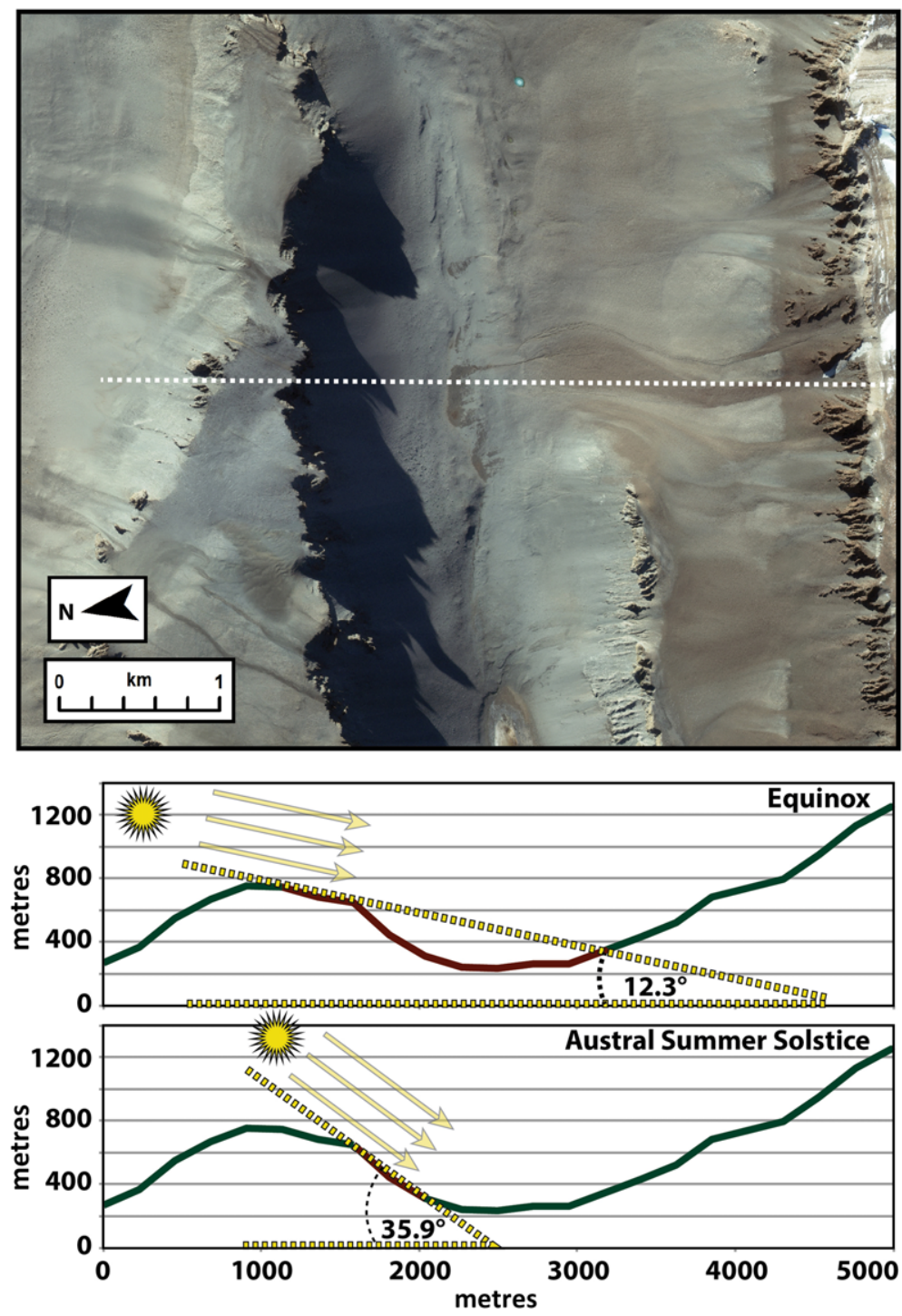

Fig. 23. Profile of the South Fork of the Upper Wright Valley with peak illumination angles overlain at the austral vernal equinox and austral summer solstice. Since the floor of South Fork does not receive significant direct insolation until late spring (November), melting conditions first occur along the valley wall. By the summer solstice, melting can occur on the floor of the valley.

apart is the anomalously high surface temperatures on the valley wall during mid-November (Figs 24 \& 25), coupled with predominantly subfreezing temperatures on the valley floor. We infer that these conditions promoted the generation of a large reservoir of in-channel ice (described earlier) as meltwater runoff from the alcove snowbank percolated down into the shaded valley floor region and re-froze. The base of the alcove snowpack for Gully A is c. $1.75 \mathrm{~km}$ from the top of the alluvial fan. Melting conditions within the alcove were achieved in late October 2010, while erosion of the Gully A fan did not begin until 18 December 2010. Meltwater would have pulsed down the channel for Gully A at an average rate of $c .41 \mathrm{~m} /$ day before reaching the floor of South Fork.

After a relatively cool late November (Fig. 24) and early December (Fig. 11) on the floor of the valley, warmer conditions resumed on 6 December 2010, 3 days before flood conditions commenced 
Surface Temperature (South Valley Wall)
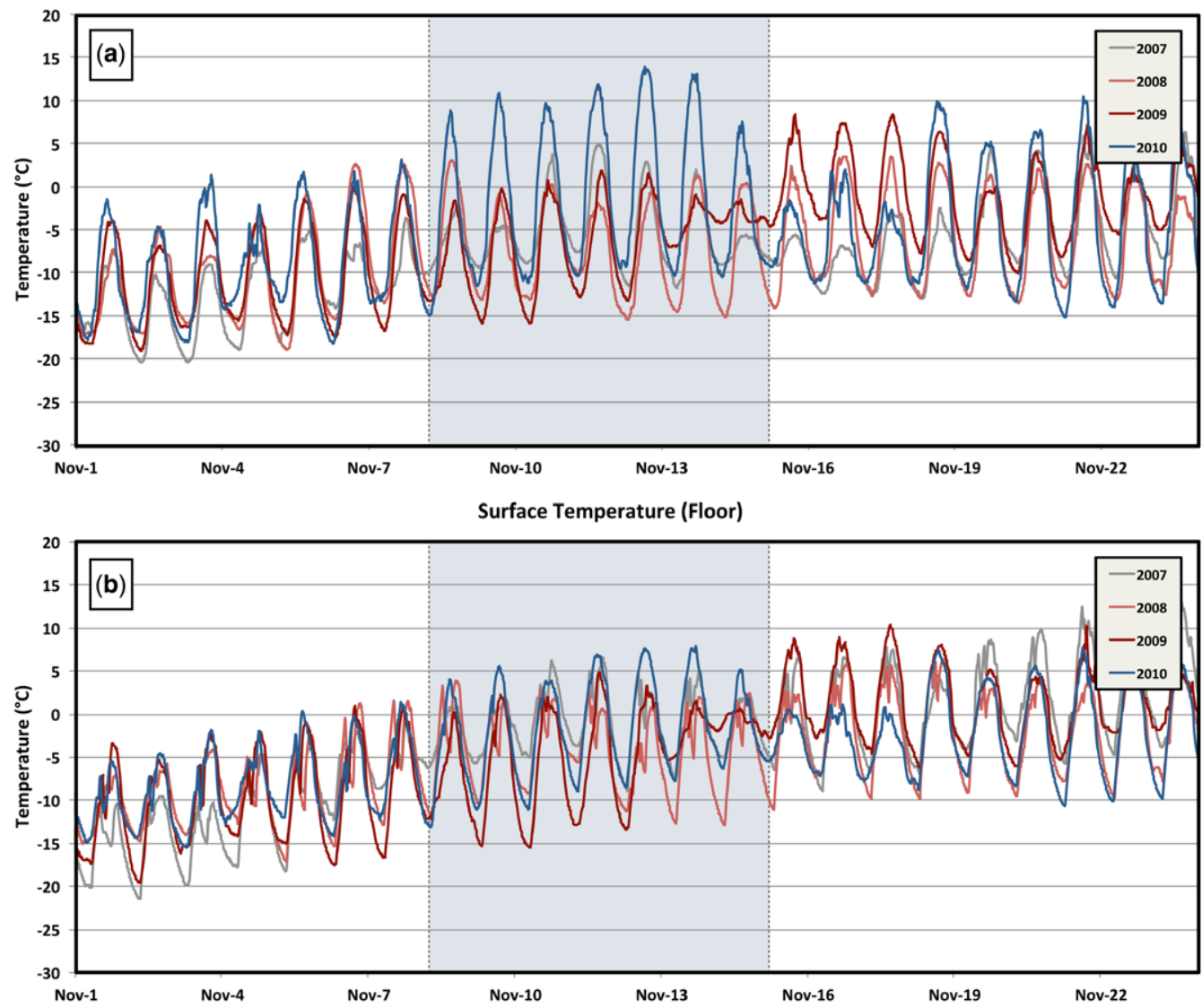

Fig. 24. Surface-temperature records for (a) the valley wall and (b) the valley floor in November for 2007-10. Extremely warm conditions were observed on the valley wall during November 2010, yet this warmth was not recorded on the valley floor, which is still shaded at this time of the year by the steep wall of the Dais to the north.

on the fan of Gully B (SUP video 6). Warm conditions persisted for over 2 weeks, first producing the flood of Gully B, then the subsequent flood of Gully A, which lasted until 23 December 2010. The cessation of activity in Gully B despite subsequent warm conditions and the flooding of Gully A points to a finite in-channel ice reservoir that had been depleted. Likewise, the flooding of Gully A ended during warm conditions, suggesting that it, too, was sourced by a reservoir that had become extinct.

This working model for hydroclimatic conditions that produce major discharge and erosion events in South Fork gullies provides an additional set of criteria for determining when, where and how fluvial erosion and deposition occur in cold desert hydrological systems (Head \& Marchant 2014) (Fig. 26). In order to generate long-lived landforms such as channels and fans, ice reservoirs that melt to produce runoff must not only be persistent (like the alcove snowbanks) and sufficiently voluminous to generate discharge that exceeds infiltration capacity (Levy 2015), but they must also be positioned in a geometry that permits rapid heating and melt generation that can produce high-discharge flows (e.g. Hecht 2002). We have shown that in South Fork, illumination-controlled, surface-temperature patterns can mobilize water from persistent, but distant, reservoirs (e.g. alcove snowbanks) to in-channel storage locations that experience higher peak summer temperatures than the alcoves, and which, in turn, generate high-discharge flood events capable of carving persistent erosional features.

\section{Summary and conclusions}

Gullies in the South Fork of Upper Wright Valley form only where ice is able to accumulate, 

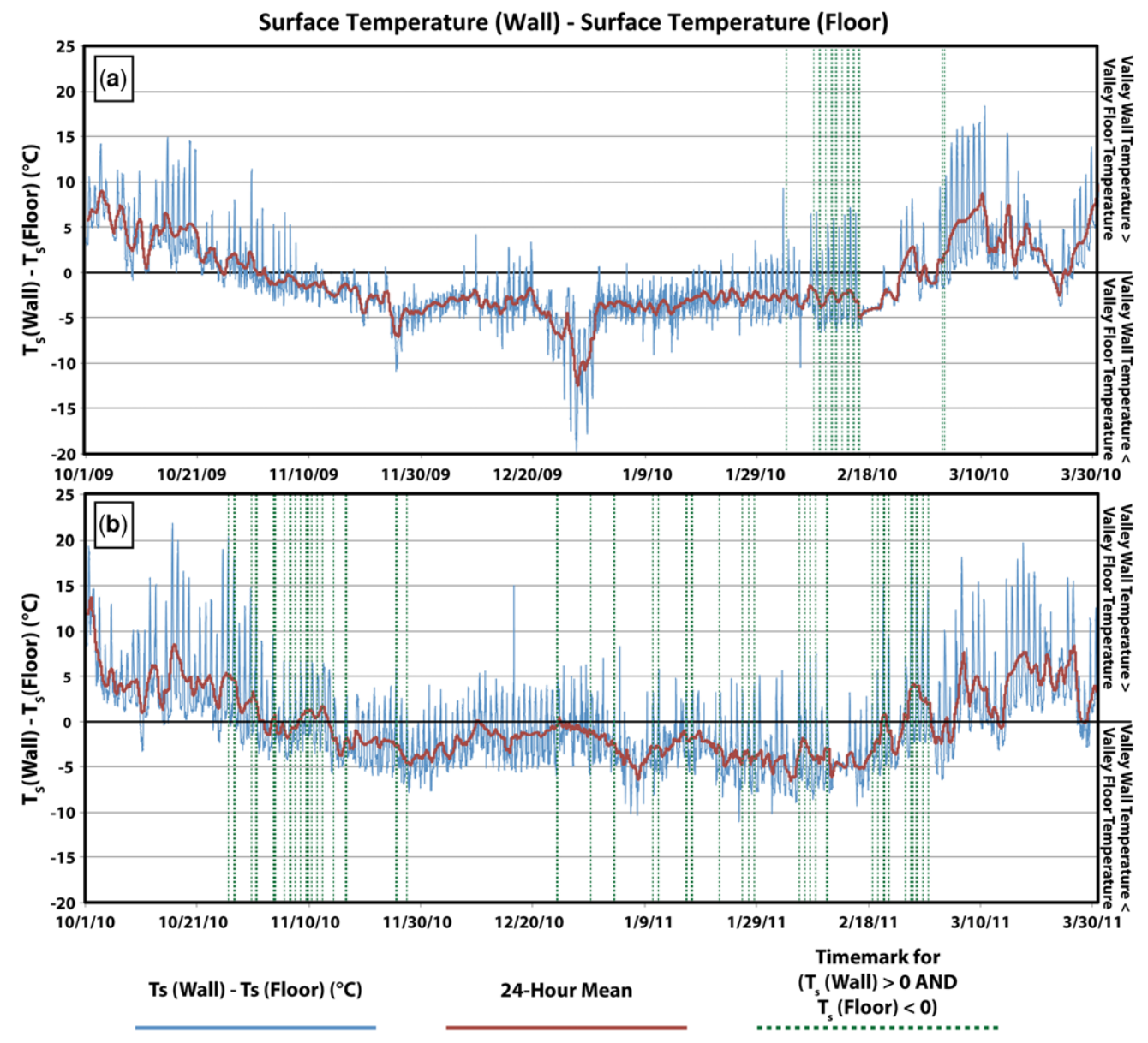

Fig. 25. (a) Difference between surface temperature on the valley wall and surface temperature on the valley floor during the entire 2009-10 season. Early in the spring (October-November) and in the autumn (March-April), the wall is warmer than the floor, but during summer (December-January) the floor is warmer than the wall. (b) Same plot for 2010-11. Plotted in green are instances when the valley wall was above freezing and the valley floor was below freezing. We infer that these conditions allow for the generation of concentrated ice reservoirs in gully channels close to the alluvial fans.

concentrate and melt: warm, equator-facing slopes. We have outlined several of the major factors in the formation of gullies in the upper part of the Inland Mixed Zone (IMZ) of the McMurdo Dry Valleys of Antarctica: (1) the distribution of ice sources (alcoves, annual snow accumulation sequestered in depressions and channels, ice-cemented soil at the base of the dry active layer, and ice sequestered in the near-surface environment in favourable insolation environments); (2) the locations, geometries and temporal aspects of ice melting; and (3) the relative significance of melting events to the processes of erosion and deposition in gully systems. We show that significant net erosion of gully channels can be achieved in a polar desert environment such as
South Fork if geometrical and environmental conditions combine to concentrate ice in regions where it can rapidly melt. Annual melting of surface ice and snow deposits, and possibly of ice cement, during late-season (January) discharge events consistently contributes to the transport of water and base-load sediments in the South Fork gullies (Fig. 10), but flux within these drainage systems rarely surpasses the infiltration capacity of the active layer, limiting the extent of overland flow. These small, but regular, discharge events do not appear to erode channels of significant width (i.e. those that can be observed using spacecraft). Even when the flux is sufficient to carve a $c$. 10-20 cm-deep channel during summer (January) runoff, these small channels seldom persist 


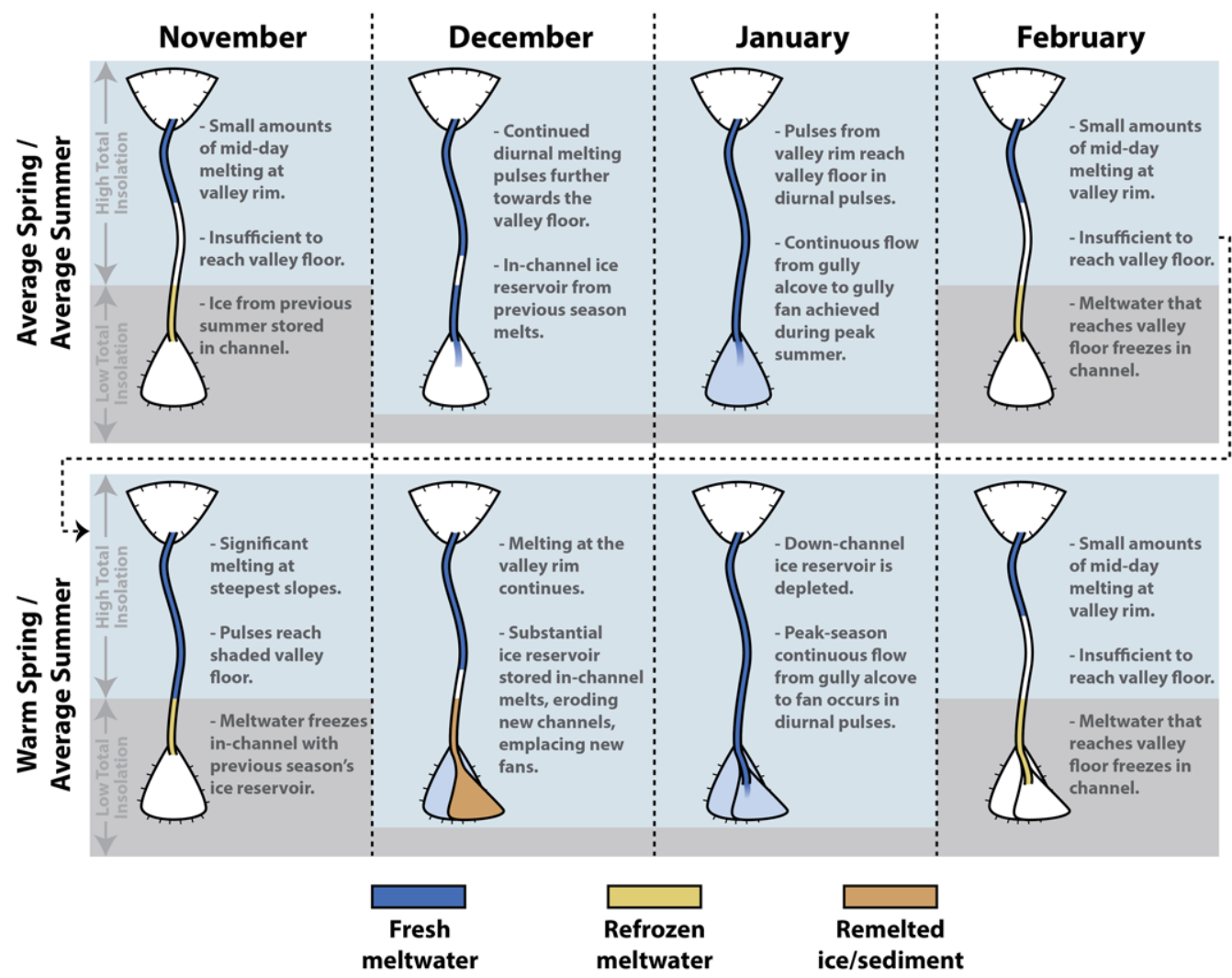

Fig. 26. Schematics for gully activity in typical seasons and during seasons with floods. (Top) Typical season: small amounts of snow and in-channel ice are stored at the lower extents of the channel, which do not melt until later in austral spring (November-December). Melting in the alcove occurs in spring (November), but flow is insufficient to reach the valley floor. During late spring and early summer (November-January), in-channel ice and snow is melted, while melting continues within gully alcoves. In January, this melting eventually reaches the channel floor and advances through small daily pulses. Later in summer (February-March), shadows cast by the Dais freeze meltwater lower in the channel. A thin sediment layer then buries this in-channel ice reservoir during winter wind storms. (Bottom) Flood events are created by increased melting during early and mid-spring (October-November), when meltwater sourced from the alcove snowpacks freezes when it reaches near the cold valley floor. This generates a concentrated in-channel ice reservoir that melts once peak insolation conditions occur in December. Once this reservoir is depleted, floods no longer occur.

through multiple seasons (Fig. 17), because they are seasonally muted and filled with aeolian deposits.

\section{Future applications to Mars?}

Gullies on Mars (Malin \& Edgett 2000) are young (Reiss et al. 2004; Schon et al. 2009), and share similar morphology and broad near-surface stratigraphy with gullies in South Fork; they are strongly correlated with (1) latitude and (2) slope orientation (Harrison et al. 2015). Gullies on Mars most commonly form on the steep walls of impact craters, which have unique insolation geometries that are similar to the north and south walls of South Fork.
During Martian winter and spring on pole-facing slopes, alcoves will receive illumination first due to the shadow cast on alluvial fans by the steep eastern/western crater walls. Thus, steep thermal gradients greater than those observed in South Fork are to be expected on these surfaces; this will evolve through Martian spring and summer as the lower reaches of gully channels receive greater solar insolation. In addition, the low density of the Martian atmosphere produces very high surface temperatures during the day (significantly above freezing in illuminated lower-latitude locations) and very low surface temperatures at night (Hecht 2002).

The regular, but ephemeral modification of South Fork gullies by 'typical' seasonal process may be an 
aid in the future analysis of relatively recent and contemporary channel erosion/exhumation on Mars attributed to phase changes of $\mathrm{CO}_{2}$ (Dundas et al. 2015; Pilorget \& Forget 2016) and liquid water (Malin \& Edgett 2000; Dickson \& Head 2009 and references therein). If the near-surface (the top several metres) stratigraphy in the Dry Valleys is similar to the mid-latitudes of Mars where gullies are found (Head et al. 2003), then channel deepening within Martian gullies should first erode through a desiccated regolith layer before combined thermal and mechanical erosion can begin cutting into a resistant underlying ice-containing permafrost layer - in this case, the latitude-dependent mantle (LDM) (Head et al. 2003).

Due to their extreme aridity and cold, both the McMurdo Dry Valleys and Mars straddle the triple point of water. Focusing studies on when and where phase changes (melting, sublimation) occur within gully systems throughout both daily and annual cycles has helped to reveal the unusual circumstances required to produce fluvial systems that leave persistent geomorphological fingerprints, even at the very limits of liquid-water stability on Earth. Our results suggest that gully erosion in polar deserts on Earth includes (and may be dominated by) rare, punctuated events in addition to gradual, iterative annual erosion.

Our documentation of the processes in the McMurdo Dry Valleys thus helps to develop a framework for investigating present-day activity within gullies on Mars, and raises the following questions: Are present-day erosive events (Dundas et al. 2015) observed to repeat every year? Can channels that have been formed/exhumed over the last decade survive dust storms (the analogue of austral winter aeolian sedimentation in the MDV)? Finally, what are the precise climatic conditions (persistent and/or punctuated) during which the major parts of gully erosion and deposition occur?

Similar observations and measurements to those presented here for the McMurdo Dry Valleys could be performed on Mars. Gullies and recurring slope lineae present challenges with regard to both accessibility, due to steep slopes, and contamination of potentially hospitable terrains. Time-lapse observations synchronized with meteorological measurements circumvent both of these issues. While this strategy has been performed with orbital data (McEwen et al. 2011; Dundas et al. 2015), this constrains both spatial and temporal resolution to the extent that definitive conclusions cannot be drawn. We suggest that our non-invasive imaging and documentation campaign in Earth's most Mars-like environment would be a powerful scientific tool on Mars itself.

We appreciate detailed and constructive reviews of this paper by Colin Dundas and an anonymous reviewer, as well as the editor, Susan Conway. Field assistance was generously provided by dozens of colleagues who were all essential for instrument implementation. In particular, we thank Mike Wyatt. We are grateful for logistical assistance from Raytheon Polar Services, Antarctic Support Contract, Petroleum Helicopters International and the summer staff of McMurdo Station. We thank the National Science Foundation Division of Polar Programs for funding several projects that contributed to this paper: ANT-0739702 to JWH, ANT-0944702 to DRM and PLR-1343649 to JSL.

\section{References}

Bindschadler, R., Vornberger, P. et al. 2008. The Landsat image mosaic of Antarctica. Remote Sensing of Environment, 112, 4214-4226, https://doi.org/10.1016/j. rse.2008.07.006

Bockheim, J.G. \& Hall, K.J. 2002. Permafrost, active-layer dynamics and periglacial environments of continental Antarctica. South African Journal of Science, 98, 82-90.

Calkin, P.E. \& Bull, C. 1972. Interaction of the East Antarctic ice sheet, alpine glaciations and sea-level in the Wright Valley area, Southern Victoria Land. In: ADIE, R.J. (ed.) Antarctic Geology and Geophysics. Universitetsforlaget, Oslo, 435-440.

Conovitz, P.A., McKnight, D.M., MacDonald, L.H., Fountain, A.G. \& House, H.R. 1998. Hydrologic processes influencing streamflow variation in Fryxell Basin, Antarctica. In: PrIscu, J.C. (ed.) Ecosystem Processes in a Polar Desert: The McMurdo Dry Valleys, Antarctica. American Geophysical Union, Antarctic Research Series, 72, 93-108.

Dickson, J.L. \& HeAD, J.W. 2009. The formation and evolution of youthful gullies on Mars: gullies as the late-stage phase of Mars' most recent ice age. Icarus, 204, 63-86.

Dickson, J.L., Head, J.W., Levy, J.S. \& Marchant, D.R. 2013. Don Juan Pond, Antarctica: Near-surface $\mathrm{CaCl}_{2}$-brine feeding Earth's most saline lake and implications for Mars. Nature Scientific Reports, 3, 1166.

Doran, P.T., McKay, C.P., Clow, G.D., Dana, G.L., Fountain, A.G., Nylen, T. \& Lyons, W.B. 2002. Valley floor climate observations from the McMurdo dry valleys, Antarctica, 1986-2000. Journal of Geophysical Research: Atmospheres, 107, 4772.

Dundas, C.M., Diniega, S. \& McEwen, A.S. 2015. Longterm monitoring of Martian gully formation and evolution with MRO/HiRISE. Icarus, 251, 244-263.

Fountain, A.G., Lyons, B.W. ET AL. 1999. Physical controls on the Taylor Valley Ecosystem, Antarctica. BioScience, 49, 961-971.

Gooseff, M.N., McKnight, D.M., Lyons, W.B. \& Blum, A.E. 2002. Weathering reactions and hyporheic exchange controls on stream water chemistry in a glacial meltwater stream in the McMurdo Dry Valleys. Water Resources Research, 38, 15-11-15-17.

Gooseff, M.N., BArRetT, J.E. \& Levy, J.S. 2013. Shallow groundwater systems in a polar desert, McMurdo Dry Valleys, Antarctica. Hydrogeology Journal, 21, 171-183.

Harrison, T.N., Osinski, G.R., Tornabene, L.L. \& JonEs, E. 2015. Global documentation of gullies with the Mars Reconnaissance Orbiter context camera and implications for their formation. Icarus, 252, 236-254. 
Hauber, E., Sassenroth, C. ET AL. In review. Debris flows and water tracks in Northern Victoria Land, continental East Antarctica: a new terrestrial analogue site for gullies and recurrent slope lineae on Mars. In: CoNway, S.J., Carrivick, J.L., Carling, P.A., De HaAs, T. \& Harrison, T.N. (eds) Martian Gullies and their Earth Analogues. Geological Society, London, Special Publications, 467.

Head, J.W. \& Marchant, D.R. 2014. The climate history of early mars: insights from the Antarctic McMurdo Dry Valleys hydrologic system. Antarctic Science, 26, 774-800.

Head, J.W., Mustard, J.F., Kreslavsky, M.A., Milliken, R.E. \& Marchant, D.R. 2003. Recent ice ages on Mars. Nature, 426, 797-802.

Head, J.W., Marchant, D.R., Dickson, J.L., Levy, J.S. \& Morgan, G.A. 2007. Transient streams and gullies in the Antarctic Dry Valleys: geological setting, processes and analogs to Mars. In: CoOPER, A.K. \& RAYMOND, C.R. (eds) Antarctica: A Keystone in a Changing World - Online Proceedings for the 10th International Symposium on Antarctic Earth Sciences. The National Academies Press (NAP), Washington, DC, 151.

Hecht, M.H. 2002. Metastability of liquid water on mars. Icarus, 156, 373-386.

LEVY, J.S. 2013. How big are the McMurdo Dry Valleys? Estimating ice-free area using Landsat image data. Antarctic Science, 25, 119-120.

LeVY, J.S. 2015. A hydrological continuum in permafrost environments: the morphological signatures of meltdriven hydrology on Earth and Mars. Geomorphology, 240, 70-82.

Levy, J.S. \& Schmidt, L.S. 2016. Thermal properties of antarctic soils: wetting controls subsurface thermal state. Antarctic Science, 28, 361-370.

Levy, J.S., Head, J.W., Marchant, D.R., Dickson, J.L. \& Morgan, G.A. 2009. Geologically recent gullypolygon relationships on mars: insights from the Antarctic Dry Valleys on the roles of permafrost, microclimates, and water sources for surface flow. Icarus, 201, 113-126.

Levy, J.S., Fountain, A.G., GoosefF, M.N., Welch, K.A. \& LyONS, W.B. 2011. Water tracks and permafrost in Taylor Valley, Antarctica: Extensive and shallow groundwater connectivity in a cold desert ecosystem. Geological Society of America Bulletin, 123, 2295-2311.

Levy, J.S., Fountain, A.G. ET AL. 2014. Water track modification of soil ecosystems in Taylor Valley, Antarctica. Antarctic Science, 26, 153-162.

Lewis, A.R., Marchant, D.R., Kowalewski, D.E., Baldwin, S.L. \& WeBb, L.E. 2006. The age and origin of the Labyrinth, western Dry Valleys, Antarctica: evidence for extensive middle Miocene subglacial floods and freshwater discharge to the Southern Ocean. Geology, 34, 513-516.

Lyons, W.B., Welch, K.A. ET AL. 2005. Groundwater seeps in Taylor Valley Antarctica: an example of a subsurface melt event. Annals of Glaciology, 40, 200-206.
Malin, M.C. \& EdgetT, K.S. 2000. Evidence for recent groundwater seepage and surface runoff on Mars. Science, 288, 2330-2335.

Marchant, D.R. \& Denton, G.H. 1996. Miocene and Pliocene paleoclimate of the Dry Valleys region, Southern Victoria land: a geomorphological approach. Marine Micropaleontology, 27, 253-271.

Marchant, D.R. \& Head, J.W. 2007. Antarctic dry valleys: microclimate zonation, variable geomorphic processes, and implications for assessing climate change on Mars. Icarus, 192, 187-222.

Marchant, D.R., Lewis, A.R. et aL. 2002. Formation of patterned ground and sublimation till over Miocene glacier ice in beacon Valley, southern Victoria Land, Antarctica. Geological Society of America Bulletin, 114, 718-730.

McEwen, A.S., Олна, L. ET AL. 2011. Seasonal flows on warm Martian slopes. Science, 333, 740-743.

McKay, C.P., Mellon, M.T. \& Friedmann, E.I. 1998. Soil temperatures and stability of ice-cemented ground in the McMurdo Dry Valleys, Antarctica. Antarctic Science, 10, 31-38.

McKnight, D.M., NiYogi, D.K., Alger, A.S., Bomblies, A., Conovitz, P.A. \& TATE, C.M. 1999. Dry Valley Streams in Antarctica: ecosystems waiting for water. BioScience, 49, 985-995.

Nylen, T.H., Fountain, A.G. \& Doran, P.T. 2004. Climatology of katabatic winds in the McMurdo dry valleys, southern Victoria Land, Antarctica. Journal of Geophysical Research, 109, D03114.

Pilorget, C. \& Forget, F. 2016. Formation of gullies on Mars by debris flows triggered by $\mathrm{CO}_{2}$ sublimation. Nature Geoscience, 9, 65-69.

Reiss, D., van Gasselt, S., Neukum, G. \& Jaumann, R. 2004. Absolute dune ages and implications for the time of formation of gullies in Nirgal Vallis, Mars. Journal of Geophysical Research: Planets, 109, 06007.

RioRdAn, A.J. 1973. The climate of Vanda Station, Antarctica. In: RaAsch, G.O. (ed.) Geology of the Arctic. University of Toronto Press, Toronto, 268-275.

Schon, S.C., Head, J.W. \& Fassett, C.I. 2009. Unique chronostratigraphic marker in depositional fan stratigraphy on mars: evidence for $c$. 1.25 Ma old gully activity and surficial meltwater origin. Geology, 37, 207-210, https://doi.org/10.1130/G25398A.1

Sugden, D.E., Marchant, D.R., Potter, N., Souchez, R.A., Denton, G.H., Swisher, C.C., III \& Tison, J.-L. 1995. Preservation of Miocene glacier ice in East Antarctica. Nature, 376, 412-414.

Thompson, D.C. 1973. Climate of the Dry Valleys area of southern Victoria land. New Zealand Geographical Society, Conference Series, 7, 259-265.

Thompson, D.C., Craig, R.M.F. \& Bromley, A.M. 1971. Climate and surface heat balance in an Antarctic dry valley. New Zealand Journal of Science, 14, 245-251.

VinCENDON, M. 2015. Identification of Mars gully activity types associated with ice composition. Journal of Geophysical Research: Planets, 120, 1859-1879. 